\title{
De toon waarop: Wat is intonatie en hoe kan het afwijken van de norm?
}

\author{
Ineke Mennen \\ Institute of English Studies, Section of Applied Linguistics, University of Graz, Graz, Austria
}

\begin{abstract}
Samenvatting
Simpel gezegd verwijst intonatie of zinsmelodie naar veranderingen in toonhoogte die in mondelinge communicatie gebruikt worden voor het weergeven van informatie. Kinderen krijgen intonatie meestal probleemloos onder de knie, ook al duurt het een tijdje voordat ze intonatie op een volwassen manier gebruiken. Toch hebben sommige mensen moeite met intonatie. Dat is niet verwonderlijk want intonatie is complex. Intonatie behelst namelijk meer dan alleen het produceren van stijgende en dalende toonhoogtebewegingen. Een ander belangrijk aspect van intonatie is het koppelen van deze bewegingen aan een functionele betekenis. Dit omvat het leren van de inventaris van fonologisch verschillende intonatiecontouren van een bepaalde taal, het uitzoeken wat hun betekenis is, wat de gebruiksfrequentie van intonatiecontouren is, en hoe ze precies uitgesproken worden onder verschillende omstandigheden. Het produceren van taalspecifieke intonatie is dus een complexe taak. Het is niet verwonderlijk dat tweede taalverwervers dit slechts zelden perfect onder de knie krijgen. Gezien de complexiteit van intonatie is het ook niet vreemd dat in sommige spraakstoornissen afwijkingen in de intonatie worden vastgesteld. In recente jaren zijn nieuwe technieken ontwikkeld om intonatie te analyseren. Deze kunnen identificeren in hoeverre en op welke manier intonatie afwijkt van de verwachting en kunnen daarmee een bijdrage leveren aan het ontwikkelen van een gericht interventieplan.
\end{abstract}

\begin{abstract}
Summary
Simply put, intonation or sentence melody refers to the changes in pitch that are used in oral communication to convey information. Children usually master intonation without any problems, even though it may take a while before they use it in a mature way. Some people, nevertheless, experience problems with intonation. That is not surprising because intonation is complex. This is because intonation involves more than just the production of rising and falling pitch movements. A further important aspect of intonation is to map these movements to functional meaning. This involves learning the inventory of phonologically distinct intonation contours for that particular language,
\end{abstract}

Correspondentieadres: Ineke Mennen, Ph.D., Institute of English Studies, Section of Applied Linguistics, University of Graz, Heinrischstraße 36, 8010 Graz, Austria

E-mail: ineke.mennen@uni-graz.at 
figuring out what their functions are, how frequent the intonation contours are used, and how they are realised in different environments. Producing language-specific intonation is therefore a complex task. It is not surprising that second language learners rarely master it perfectly. Given the complexity of intonation it is also not surprising that some speech disorders feature deviations in intonation. In recent years, new techniques have been developed to analyze intonation. These can identify to what extent and in what way intonation is different from expectation and thus contribute to the development of a targeted intervention plan.

\section{Introductie}

Mondelinge communicatie bestaat uit meer dan alleen de opeenvolging van klinkers en medeklinkers. Zo kan een reeks klanken onder andere uitgesproken worden met of zonder stemverheffing, met een toonstijging of -daling, sneller of langzamer, met een vlakke of levendige melodie. Dit soort "eigenschappen van een spraakuiting die niet herleid kunnen worden tot de opeenvolging van klinkers en medeklinkers" (Rietveld \& van Heuven, 2009: 277 ) is wat in de taalwetenschap prosodie genoemd wordt. Prosodie kan informatie toevoegen aan de boodschap die door de woorden en grammatica van een zin wordt gegeven. Zo kan de prosodie informatie geven over hoe een bepaalde uiting geïnterpreteerd moet worden en een nuancering aan de informatie geven. Een stijgende of dalende intonatie kan aangeven of een uiting bedoeld is als een vraag of een verklaring. Prosodie kan ook aangeven welk woord belangrijk is en welk minder en welke woorden bij elkaar horen. Verder kan prosodie informatie geven over de stemming van de spreker of zijn houding ten opzichte van iets of iemand. Zo kunnen we afleiden of een spreker gehaast of geagiteerd is, of juist bezorgd, blij of verdrietig. Deze voorbeelden maken duidelijk dat de term prosodie een verzamelterm is die verwijst naar een reeks verschijnselen zoals intonatie, klemtoon, ritme, tempo, pauze en duur.

Prosodie speelt een belangrijke rol in mondelinge communicatie. Wanneer de prosodie verkeerd of afwijkend is zal dit in veel gevallen de communicatie verstoren. Onderzoek heeft bijvoorbeeld aangetoond dat zwakke prosodische vaardigheden van grote invloed zijn op de verstaanbaarheid van gesproken taal, soms zelfs meer dan zwakke vaardigheden in de productie van klanken (bijv. Anderson-Hsieh e.a. 1992; Boula de Mareüil \& Vieru-Dimulescu, 2006; Magen, 1998, Munro \& Derwing 1995). Toch wordt er over het algemeen meer aandacht besteed aan onderzoek naar afwijkende klanken dan aan onderzoek naar een afwijkende prosodie (Mennen, 2015). Dat is jammer want er is in de laatste decennia veel vooruitgang geboekt in de wetenschap van de prosodie, met name op het gebied van intonatie. Vooral de invloedrijke "autosegmentele-metrische" (AM) benadering van intonatie, bekend door het werk van Pierrehumbert (1980) en Pierrehumbert \& Beckman (1988) (zie ook Ladd, 2008 , voor een overzicht), heeft gezorgd voor een enorme toename aan studies over intonatie en hoe intonatiesystemen tussen talen, dialecten en regiolecten verschillen. Een belangrijk aspect van de AM benadering is dat er een onderscheid gemaakt wordt tussen o.a. 
de fonologische en fonetische bestanddelen van intonatie (meer gedetailleerde uitleg volgt later). Dit onderscheid wordt gezien als zeer waardevol voor de analyse van spraakstoornissen (bijv. Kent \& Kim, 2003; Mennen e.a., 2008). Als er fonetische afwijkingen geconstateerd worden duidt dit meestal op onderliggende fysiologische veranderingen (zoals een gebrek aan ademsteun, coördinatie, of een gereduceerd articulatorisch bereik), terwijl fonologische afwijkingen eerder duiden op een verstoring van het intonatiesysteem zelf of met de planning en programmering van intonatie (Mennen, e.a., 2008; Kuschman e.a., 2012). Een dergelijke analyse van intonatieproblemen is niet alleen zinvol in onderzoek naar spraakstoornissen, maar kan net zo informatief zijn bij het beoordelen van de intonatie-ontwikkeling in kinderen, tweetalige sprekers, of tweede taalverwervers en om te bepalen in hoeverre deze afwijken van volwassenen en eentalige sprekers (Mennen, 2015).

Dit artikel beperkt zich voornamelijk tot het bespreken van één van de prosodische verschijnselen, namelijk intonatie. Er wordt beschreven wat intonatie is en hoe het kan verschillen tussen talen, taalvariëteiten, en individuele sprekers. Daarna worden methodologische aspecten van intonatieonderzoek besproken. Daarbij wordt de nadruk gelegd op methodes om te bepalen waar, hoe, en in welke mate, intonatie kan afwijken van een bepaalde norm. Afsluitend wordt een overzicht gegeven van bestaand onderzoek naar afwijkende intonatie die van toepassing zou kunnen zijn op de klinische praktijk.

\section{Intonatie}

De term intonatie, soms ook zinsmelodie of spraakmelodie genoemd, verwijst naar veranderingen in toonhoogte die in mondelinge communicatie gebruikt worden voor het weergeven van informatie. Deze toonhoogteverschillen hangen samen met variatie in de snelheid waarmee de stembanden trillen. Hoe sneller de stembanden trillen hoe hoger de grondtoonfrequentie (f0). De term f0 wordt dus gebruikt voor het akoestische en meetbare gevolg van de snelheid waarmee de stembanden trillen in stemhebbende spraak. Dit verloop van hogere en lagere f0 komt min or meer overeen met wat luisteraars horen als toonhoogtevariatie (Nolan, 2006). De term toonhoogte verwijst dus naar het hoorbare gevolg van de snelheid waarmee de stembanden trillen.

Deze veranderingen in toonhoogte staan los van de woorden en klanken die gebruikt worden. Dat wil zeggen, intonatie verschilt van tonen die we tegenkomen in toontalen (zoals bijv. in het Mandarijn en Kantonees) waar veranderingen in toonhoogte gebruikt worden om woorden van elkaar te onderscheiden. Hoewel intonatie vooral een kwestie van variatie in toonhoogte is, gaat het vrijwel altijd gepaard met variatie in andere prosodische kenmerken, zoals bijv. luidheid, klemtoon, ritme, en tempo. Daarom kan intonatie niet los worden gezien van deze andere prosodische kenmerken.

Figuur 1 laat akoestische analyses zien van de uiting 'Gaat Melina met ons mee?', gesproken met nadruk op Melina (alsof de spreker wil checken of het inderdaad Melina is die 


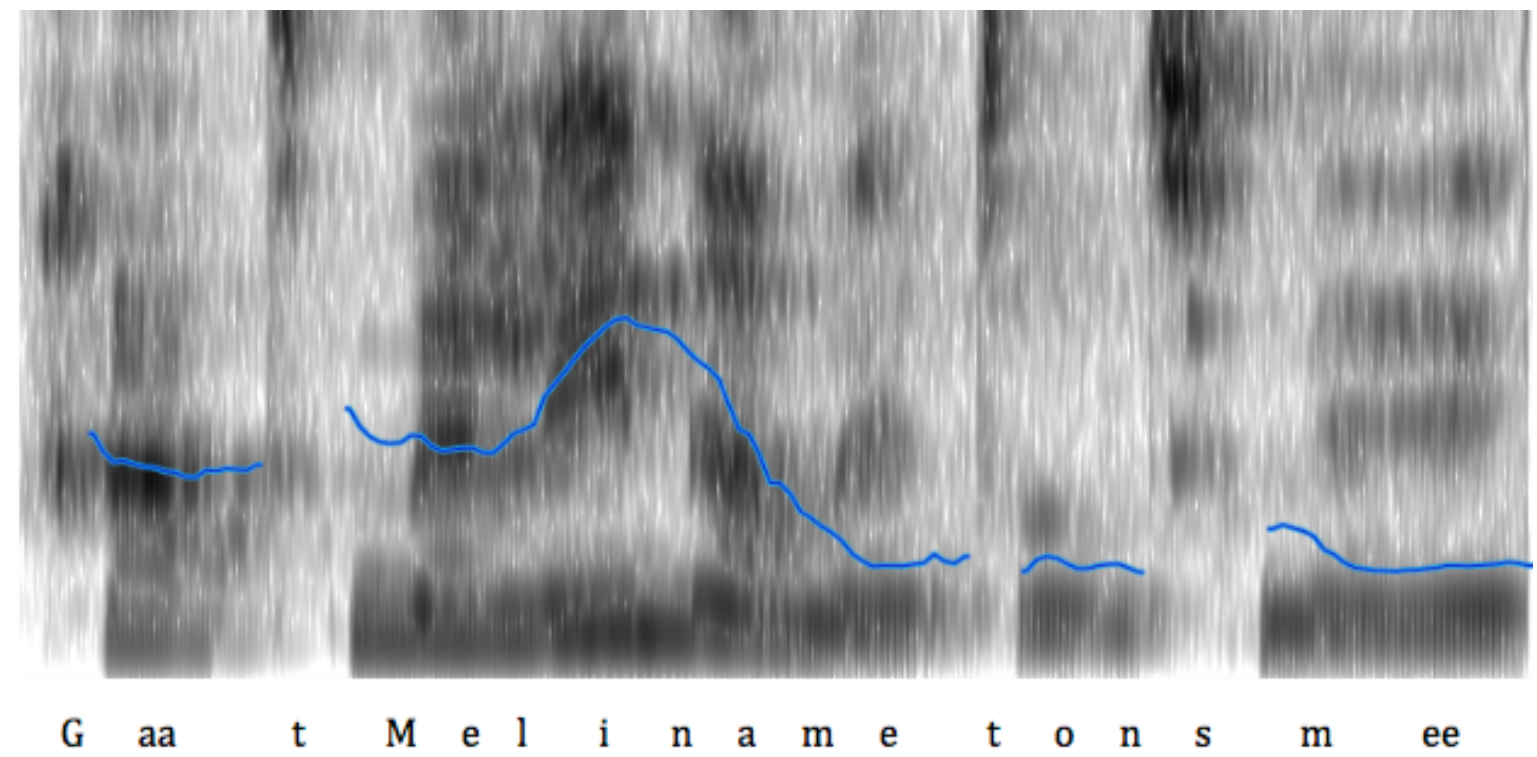

Figuur 1: Akoestische representatie van 'Gaat Melina met ons mee?': spectrogram met daaroverheen de blauwe curve van de grondtoonfrequentie.

meegaat, en niet iemand anders). De grijsgradaties komen van een zogeheten spectrogram dat een visuele weergave is van hoe de geluidsgolven en -resonanties veranderen tijdens het spreken van de zin 'Gaat Melina met ons mee?'. De horizontale as geeft de tijd aan, terwijl de verticale as de frequentie van de geluidsresonanties in Hertz aangeeft. De mate van grijsgradatie geeft de intensiteit weer: hoe zwarter hoe groter de intensiteit. Voor de duidelijkheid is er orthografisch weergegeven welke delen van het spectrogram overeenkomen met de gesproken uiting. Met behulp van een spectrogram kan men klinkers herkennen aan de enigszins golvende donkere balken. Dit is bijvoorbeeld goed te zien in het woord 'mee' aan het einde van de zin, waar we vier duidelijke donkere balken boven elkaar zien (en als je goed kijkt ook nog een vrij lichte vijfde balk bovenaan). Aan de hand van een spectrogram kunnen we ook de duur van een klinker of medeklinker, of van lettergrepen, woorden of zinnen bepalen. We kunnen bijvoorbeeld van het spectrogram in figuur 1 afleiden dat de zin zonder duidelijke pauzes tussen de woorden is uitgesproken. Als er namelijk een pauze tussen de woorden was geweest, dan zou de afwezigheid van geluidsgolven voor een witte strook in het spectrogram gezorgd hebben.

De blauwe curve in figuur 1 geeft de grondtoonfrequentie (f0) van de gesproken uiting aan. Deze is op dezelfde tijdschaal bovenop het spectrogram getekend en geeft het intonatieverloop van de zin weer. We zien dat de zin begint met een midden-hoge f0 waarde op 'gaat', waarna de f0 lichtelijk stijgt en dan scherp stijgt op '-li' (van Melina). Dit wordt gevolgd door een scherpe daling op '-na' (van Melina), waarna de f0 laag blijft tot het einde van de zin. Misschien is het opgevallen dat de f0-contour nogal grillig van aard is en op som- 
mige plekken zelfs onderbroken wordt. Behalve de grote stijging-daling op 'Melina', zijn er ook wat kleine stijgingen en dalingen te zien. Deze kleine toonhoogteveranderingen worden grotendeels door de luisteraar genegeerd omdat ze niet wezenlijk zijn voor de waarneming van de zinsintonatie. De onderbrekingen in het f0-patroon worden veroorzaakt door stemloze medeklinkers. Aangezien de grondtoonfrequentie bepaald wordt door de trilling van de stembanden, kunnen stemloze klanken geen grondtoonfrequentie hebben omdat de stembanden dan niet trillen. Dit is te zien bij de [t] in 'gaat' en 'met', of de [s] in 'ons'. Pauzes tussen woorden zorgen ook voor een onderbreking van de f0-contour. Ondanks deze onderbrekingen in het f0-patroon kunnen we de melodie toch goed horen.

De grote stijging op de beklemtoonde lettergreep -li in 'Melina' is wèl belangrijk voor de waarneming van de zinsintonatie. Deze stijging, gevolgd door een snelle daling in de volgende lettergreep, zorgt ervoor dat het woord 'Melina' geaccentueerd wordt. Eerder werd opgemerkt dat intonatie niet los gezien kan worden van andere prosodische verschijnselen. Zo is bijvoorbeeld te zien dat de geaccentueerde lettergreep -li in 'Melina' langer is dan de andere twee lettergrepen in dit woord. Verder is te zien dat de klankreeks [me] in 'mee' zeker twee keer zolang is als dezelfde klankreeks in 'Melina'. Dit komt omdat in het eerste geval, deze lettergreep beklemtoond is en in het tweede geval niet. Bovendien worden lettergrepen aan het einde van een intonatiepatroon (bijv. aan het einde van een zin) altijd verlengd.

\section{Hoe kan intonatie tussen talen en dialecten vergeleken wor- den?}

Intonatie kan behoorlijk variëren. Afhankelijk van de communicatieve betekenis die men wil overdragen, zou de zin in Figuur 1 bijvoorbeeld ook met een vragende intonatie uitgesproken kunnen worden, of met nadruk op 'ons' in plaats van op 'Melina'. Daarnaast kan intonatie aanzienlijk verschillen van spreker tot spreker (bijv. tussen mannen en vrouwen), van moment tot moment (bijv. enthousiaste vergeleken met verveelde spraak), tussen spraakvormen (bijv. tussen een voorgelezen tekst en spontane spraak), talen, en dialecten (Ladd, 2008). Dit maakt het niet gemakkelijk om intonatievergelijkingen te maken. Ladd (2008: 115-130) stelt daarom voor dat het mogelijk en nuttig is om intonatieverschillen te classificeren in soorten of dimensies. Als ze verschillen in de set intonatiepatronen die ze tot hun beschikking hebben, is er sprake van zogenoemde systemische verschillen. Als talen of dialecten daarentegen verschillen in de uitspraak van hetzelfde intonatiepatroon, spreken we van realisatieverschillen. Daarnaast kunnen talen of dialecten ook verschillen in de betekenis of het gebruik van hetzelfde intonatiepatroon. Dit soort verschillen wordt semantische verschillen genoemd. In de volgende secties gaan we nader in op deze verschillende dimensies van intonatie. Daarnaast gaan we in sectie "Verschillen in gebruiksfrequentie van intonatiepatronen" nader in op een vierde, niet door Ladd (2008) vermeldde dimensie waarin intonatie kan verschillen, namelijk de gebruiksfrequentie van bepaalde intonatiepatronen. 


\section{Systemische (fonologische) verschillen in intonatie}

Talen of taalvariëteiten kunnen verschillen in de intonatiecontouren die ze hebben. Met andere woorden, ze kunnen verschillen in de fonologie van intonatie. Het gebruik van de term 'fonologie' met betrekking tot intonatie impliceert dat intonatie structuur heeft en bestaat uit discrete, categorische elementen. Volgens de eerder in sectie "Intonatie" vermelde autosegmentelemetrische (AM) beschrijvingen van intonatie zijn de categorische elementen hoge $(\mathrm{H})$ of lage $(\mathrm{L})$ tonen. Deze hoge en lage tonen vormen als het ware de toonhoogtedoelen die een spreker wil bereiken. De toonhoogtebewegingen (de 'melodie') ontstaat wanneer die toonhoogtedoelen met elkaar verbonden worden tijdens het spreken. De tonen kunnen onderverdeeld worden in twee soorten, afhankelijk van waar ze in een zin verschijnen. Wanneer de tonen op (of nabij) geaccentueerde lettergrepen verschijnen worden ze toonhoogteaccenten genoemd. Verschijnen ze aan de grenzen van intonatiefrases, dan worden ze grenstonen genoemd. Iedere intonatiecontour heeft minimaal één toonhoogteaccent. Een toonhoogteaccent kan bestaan uit een enkele toon (bijv. $\mathrm{H}^{*}$ of $\mathrm{L}^{*}$ ), een combinatie van twee (HL*, $\mathrm{H}^{*} \mathrm{~L}$, etc.) of zelfs drie tonen $\left(\mathrm{H}^{*} \mathrm{LH}, \mathrm{L}^{*} \mathrm{HL}\right.$ ). De asterisk geeft aan welke toon op (of nabij) de beklemtoonde lettergreep verschijnt. De grenstonen aan het einde van een intonatiefrase worden aangegeven door een $\mathrm{H}$ of $\mathrm{L}$ toon gevolgd door een percentageteken (L\% of $\mathrm{H} \%)$. De afwezigheid van grenstonen aan het einde van een intonatiefrase kan aangegeven worden met $0 \%$. Dit duidt op een vlak toonverloop aan het einde van de intonatiefrase. Tabel 1 geeft een beschrijving van veel voorkomende toonhoogteaccenten en grenstonen. Door de combinatie van een of meerdere toonhoogteaccenten met grenstonen kunnen verschillende intonatiepatronen gevormd worden.

Tabel 1: Notatie en beschrijving van veel voorkomende toonhoogteaccenten en grenstonen.

\begin{tabular}{ll}
\hline Notatie & Beschrijving \\
\hline \multicolumn{2}{l}{ Toonhoogteaccenten (Engelse term: pitch accents) } \\
$\mathrm{H}^{*} \quad$ vlakke hoge toon \\
$\mathrm{L}^{*}$ & vlakke lage toon \\
$\mathrm{H}^{*} \mathrm{~L}$ & daling \\
$\mathrm{L}^{*} \mathrm{H}$ & stijging \\
$\mathrm{H}^{*} \mathrm{LH}$ & daling-stijging \\
$\mathrm{L}^{*} \mathrm{HL}$ & stijging-daling \\
& \\
Grenstonen (Engelse term: boundary tones) \\
$\mathrm{H} \%$ & hoge grenstoon \\
$\mathrm{L} \%$ & lage grenstoon \\
$\%$ & vlak toonverloop aan einde intonatiefrase \\
\hline
\end{tabular}

Zo zien we in (1) een gestileerde intonatiecontour van de zin 'Gaat Melina met ons mee?' die we eerder al in Figuur 1 zagen. In dit voorbeeld is er slechts één toonhoogteaccent in de 
zin, namelijk op 'Melina'. Deze wordt gerealiseerd door een $\mathrm{H}^{*} \mathrm{~L}$ toonhoogteaccent, waarbij de hoge toon op de beklemtoonde lettergreep -li in 'Melina' valt en de daling in de volgende lettergreep plaatsvindt. $\mathrm{Na}$ de daling blijft de intonatie laag en treedt er geen verandering meer op in het toonverloop aan het einde van de intonatiefrase. Dit wordt aangegeven met de notatie $0 \%$, wat duidt op de afwezigheid van een grenstoon.

(1) Gaat MeLINa met ons mee?

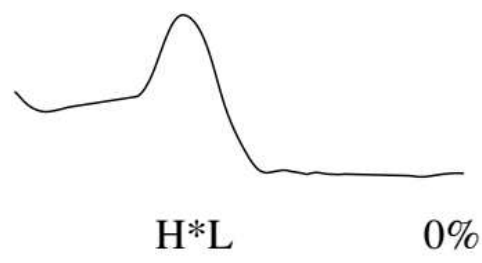

In (2) zien we twee zinnen die goed illustreren waarom een classificatie van tonen in toonhoogteaccenten en grenstonen nodig is. Op het eerste gezicht is het niet aan de intonatiecontour duidelijk of we in het voorbeeld 'Melina?' te maken hebben met een toonhoogteaccent met drie tonen $\mathrm{H}^{*} \mathrm{LH}$ (een stijging-daling-stijging) of met een toonhoogteaccent met twee tonen $\left(\mathrm{H}^{*} \mathrm{~L}\right)$ gevolgd door een hoge grenstoon $(\mathrm{H} \%)$. Als we echter meer woorden toevoegen maar hetzelfde intonatiepatroon behouden, is te zien dat de laatste stijging tot het einde van de intonatiefrase wordt uitgesteld. Dit duidt erop dat die laatste stijging een grensfenomeen is.

(2) MeLINa?

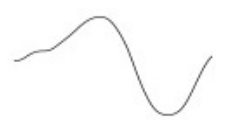

$\mathrm{H}^{*} \mathrm{~L} \quad \mathrm{H} \%$
Gaat MeLINa met ons mee?

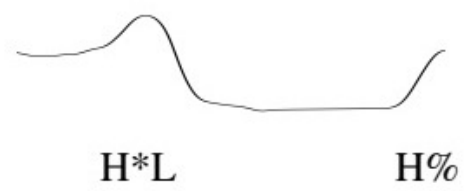

Het is ook mogelijk om dezelfde reeks woorden met een ander intonatiepatroon uit te spreken door bijvoorbeeld een ander toonhoogteaccent en/of een andere grenstoon te kiezen, óf door het aantal toonhoogteaccenten te veranderen. Als we bijvoorbeeld de zin 'Gaat Melina met ons mee' in (1) vergelijken met dezelfde zin in (2), zien we dat ze verschillen in grenstoon. De hoge grenstoon in het laatste voorbeeld geeft de zin een vragende intonatie. In (3) is dezelfde zin te zien maar nu met een stijgend $\left(L^{*} H\right)$ i.p.v. dalend toonhoogteaccent $\left(\mathrm{H}^{*} \mathrm{~L}\right)$, terwijl (4) de zin laat zien met een vlak hoog toonhoogteaccent $\left(\mathrm{H}^{*}\right)$. 
(3) Gaat MeLINa met ons mee?

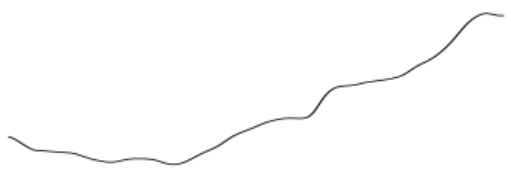

\section{$\mathrm{L} * \mathrm{H} \quad \mathrm{H} \%$}

(4) Gaat MeLINa met ons mee?

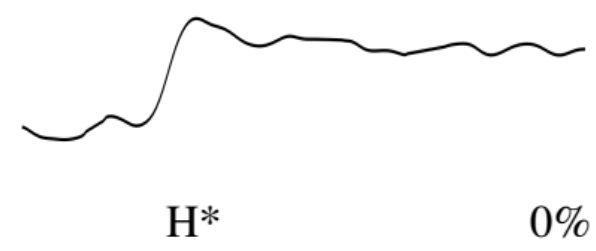

In (4) is ook te zien dat de intonatie na de vlakke hoge toon hoog blijft en er geen verandering meer optreedt in het toonverloop aan het einde van de intonatiefrase. Dit wordt net als in (1) aangegeven met de notatie $0 \%$ en duidt op de afwezigheid van een grenstoon. In voorbeeld (5) zien we een voorbeeld met twee toonhoogteaccenten in de zin 'Melina gaat met ons mee', namelijk op 'Melina' en op 'ons'.

(5) MeLINa gaat met ONS mee

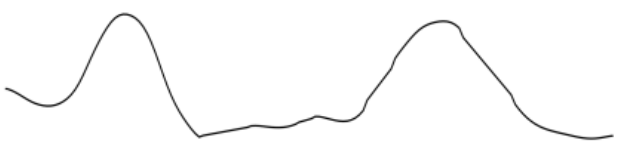

$\mathrm{H}^{*} \mathrm{~L} \quad \mathrm{H}^{*} \mathrm{~L} \quad \mathrm{~L} \%$

Talen kunnen verschillen in de set van categorische elementen die ze hebben. Dat wil zeggen, een contrast dat in de ene taal of dialect gemaakt wordt is afwezig in de andere. Net als talen kunnen verschillen in de categorische elementen van klanken (zodat er bijv. in het Schots Engels geen onderscheid is in de klinkers in Luke and look, terwijl de uitspraak van deze klinkers in andere Engelse dialecten wel verschilt), zo kunnen talen ook verschillen in de set van intonatiecontouren die ze tot hun beschikking hebben (Ladd, 2008). Zo kent het Amerikaans Engels bijvoorbeeld niet de zogeheten 'rise-plateau-slump' (een L*HL\% oftewel een stijging op de beklemtoonde syllabe gevolgd door een geleidelijke daling of een steilere daling aan het einde van de intonatiefrase), terwijl deze wel voorkomt in het Engels gesproken in het noorden van Groot-Brittannië (Cruttenden, 2001; Ladd, 2008). Een ander voorbeeld is de dalend-stijgende intonatie op 'ziek' die we in het Nederlands kennen in een zin als 'Maar je bent toch niet ziek?'. Deze dalend-stijgende intonatie komt in het Frans niet voor (Peters e.a., 2012). 


\section{Realisatieverschillen in intonatie}

Niet alle aspecten van intonatie zijn categorisch van aard zoals de toonhoogteaccenten en grenstonen. Zo zouden we een spreker kunnen vragen een bepaalde zin te herhalen, steeds met hetzelfde intonatiepatroon. Elke herhaling is een fysieke manifestatie van een identiek intonatiepatroon dat steeds ietsje anders uitgesproken wordt. Maar deze variatie in de uitspraak van 'Mijn MAMa was er net' (waar hoofdletters nadruk aangeven) in voorbeeld (6) leidt niet tot grote betekenisverschillen.

(6)

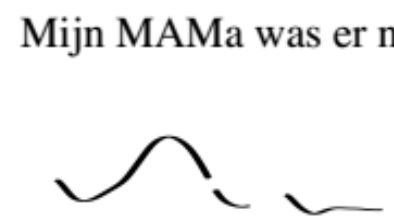

Mijn MAMa was er net

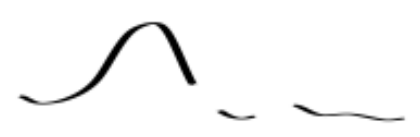

Mijn MAMa was er net

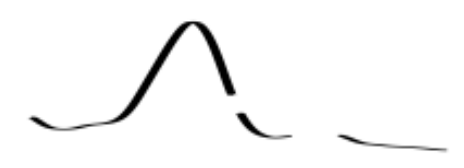

Alhoewel er verschillende gradaties zijn in de nadruk die op 'mama' wordt gelegd (men kan over het algemeen stellen dat hoe groter het toonhoogtebereik hoe nadrukkelijker de uitspraak wordt), geven alle drie uitspraken in essentie dezelfde boodschap weer. In principe zouden we een oneindig aantal uitspraken van dit intonatiepatroon kunnen produceren, terwijl de betekenis niet met elke herhaling in proportioneel evenredige wijze verandert. Met andere woorden, deze variatie is niet discreet maar vindt plaats binnen een continuüm. Een ander voorbeeld van zulke niet-categorische intonatieverschillen is de toonhoogte waarop iets wordt uitgesproken. Mannen en vrouwen verschillen in de lengte van hun stembanden. Vrouwen hebben aanzienlijk kortere stembanden dan mannen (lengtes van 13-17 mm voor vrouwen en 17-24 mm bij mannen worden gerapporteerd, Rietveld \& van Heuven, 2009). Langere stembanden trillen niet zo snel als kortere stembanden, dus hebben mannen een lagere gemiddelde spreektoonhoogte dan vrouwen. In feite zijn er grote individuele verschillen in de gemiddelde spreektoonhoogte tussen mensen, zodat eenzelfde intonatiepatroon uitgesproken door een tiental mannen en vrouwen, een tiental verschillende toonhoogtegemiddeldes kan opleveren.

Figuur 2 geeft een voorbeeld van hetzelfde intonatiepatroon uitgesproken door drie mannen en drie vrouwen. Het is duidelijk te zien dat alle zes sprekers hetzelfde intonatiepatroon produceren. Ze beginnen allemaal op een midden-lage toonhoogte, waarna de toonhoogte stijgt naar een piek en daarna daalt. Waarin de sprekers verschillen is in het register waarin ze dit intonatiepatroon produceren. We zien hier duidelijk twee groepen: de mannelijke sprekers (M1, M2 en M3) hebben een beduidend lagere toonhoogte dan de vrouwelijke sprekers (F1, F2 en F3). Ook kan men binnen de groepen verschillen zien. Spreker F2 heeft een hogere stem dan spreker F1. Dit soort realisatieverschillen wordt door luisteraars grotendeels genegeerd in de interpretatie van de intonatiecontour, die immers steeds hetzelfde blijft. Dit soort realisatieverschillen in intonatie kunnen we een beetje vergelijken met realisatieverschillen in klanken. Het maakt niet zoveel uit of je in het Nederlands de klinker [i] 


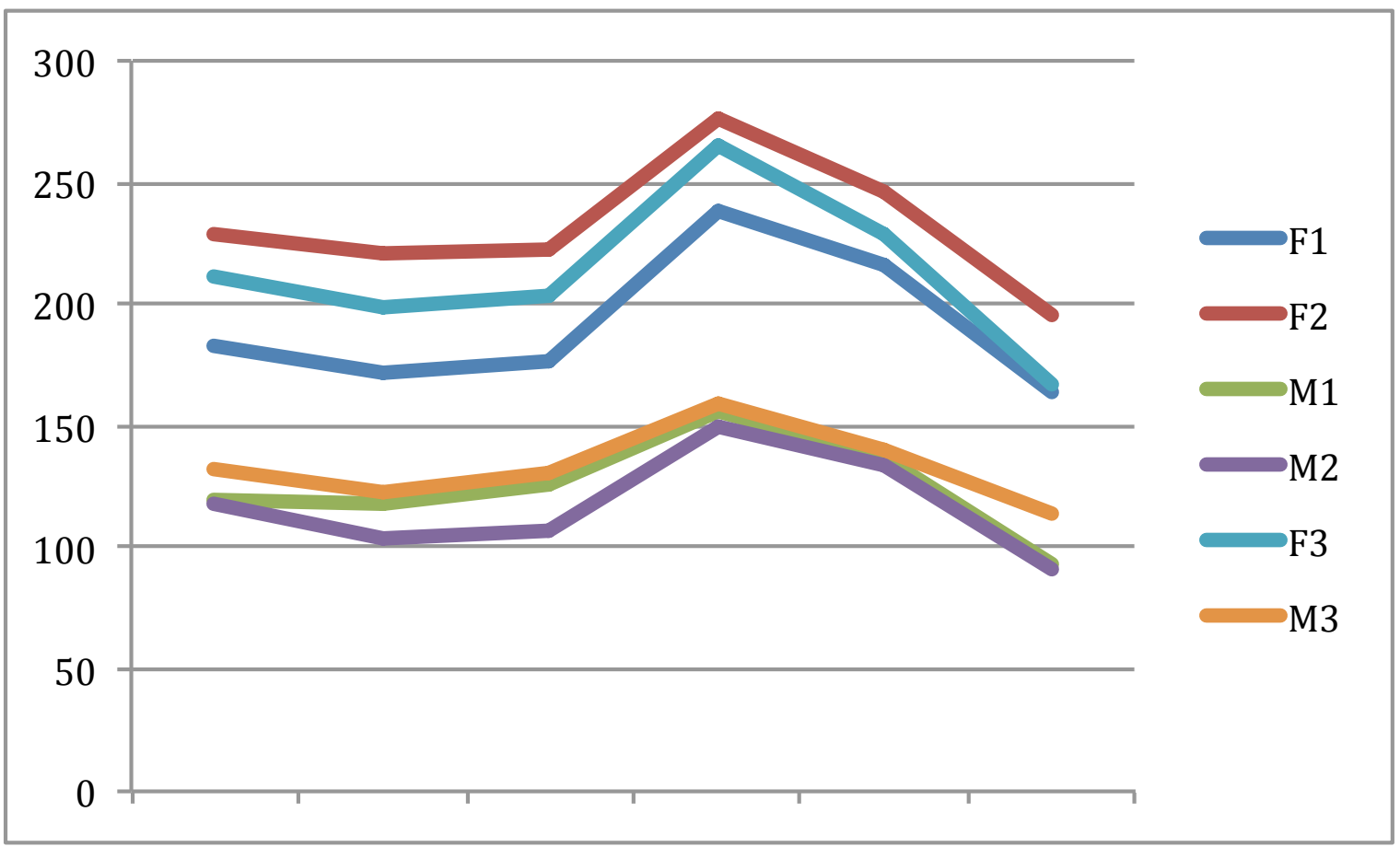

Figuur 2: Een gestileerd intonatiepatroon waar verschillen in toonhoogte tussen mannen (M1, M2, M3), vrouwen (F1, F2, F3) en individuen wordt geïllustreerd.

in biet een klein beetje langer of korter aanhoudt, het blijft een [i] en verandert de betekenis van het woord niet (dit gebeurt pas als je de klinker vervangt door bijv. een [ə] als in bot, maar dan is er sprake van een categorisch verschil).

Talen kunnen ook in deze 'niet-fonologische' aspecten van intonatie van elkaar verschillen. Ze kunnen bijvoorbeeld verschillen in het gemiddeld toonhoogtebereik dat normaliter door hun sprekers gebruikt wordt. Zo hebben sprekers van het Duits of het Nederlands over het algemeen een beduidend kleiner toonhoogtebereik dan sprekers van het Engels (Mennen, e.a., 2012; Willems, 1982; 't Hart \& Cohen, 1973). Figuur 3 laat de gemiddelde toonhoogtewaarden voor het Engels, Duits en Nederlands zien. Engelse sprekers hebben het grootste gemiddeld toonhoogtebereik ( 14 semitonen $^{1}$, Mennen e.a., 2012), gevolgd door Duitse (11 semitonen, Mennen e.a., 2012) sprekers, Nederlandse sprekers hebben het kleinste toonhoogtebereik (6 semitonen, 't Hart \& Cohen, 1973).

Een ander realisatieverschil is de plaats in de lettergreep waar doelwaarden van hoge of lage toonhoogteaccenten worden bereikt. Zo heeft het Grieks veel latere toonhoogtepieken dan het Nederlands. Terwijl in het Nederlands de toonhoogte haar hoogste punt in

\footnotetext{
${ }^{1}$ Een semitoon geeft een 6 procent verschil tussen twee toonhoogtefrequenties weer. Twaalf semitonen vormen samen een octaaf.
} 


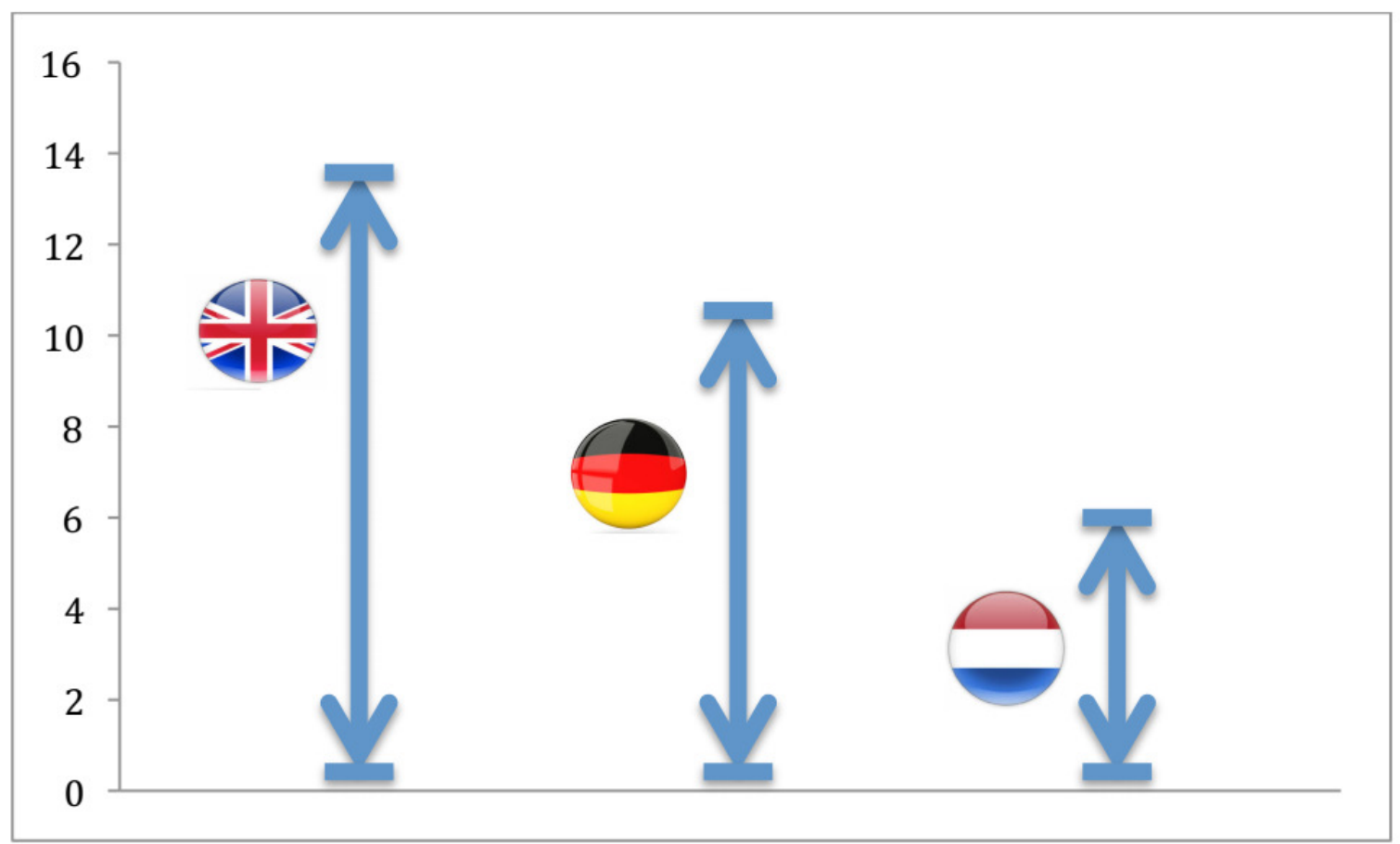

Figuur 3: Illustratie van het gemiddeld toonhoogtebereik van sprekers van het Engels, Duits, en Nederlands, gebaseerd op gegevens van Mennen e.a. (2012) voor het Engels en Duits, en 't Hart \& Cohen (1973) voor het Nederlands.

de tweede helft van de klinker van een beklemtoonde lettergreep bereikt (Ladd e.a., 2000), wordt in het Grieks het hoogste punt pas in de klinker van de daarop volgende lettergreep bereikt (Arvaniti e.a., 1998). Figuur 4 geeft de verschillen tussen de plaats van toonhoogtepieken in het Nederlands en Grieks schematisch weer.

\section{Semantische verschillen in intonatie}

Intonatie kan verschillende soorten informatie weergeven. Intonatie kan de luisteraar bijvoorbeeld helpen bij het bepalen van het zinstype. Zo verschillen in veel talen de intonatiepatronen in vragende en stellende zinnen. In het Nederlands eindigen vragende zinnen vaak (maar niet altijd) met een toonhoogtestijging ( $\mathrm{H} \%)$, terwijl stellende zinnen eerder eindigen met een toonhoogtedaling (L\%) (Haan, 2002). Intonatie kan ook gebruikt worden om frasegrenzen in zinnen aan te geven, oftewel om informatie te groeperen. Tijdens het praten moeten we regelmatig inademen om door te kunnen spreken, want onze longcapaciteit is beperkt. Nu blijkt dat we vaak ademhalen op het moment dat er een belangrijke breuk in de zinsstructuur is, bijvoorbeeld op plaatsen waar we in schriftelijke communicatie een komma of punt zouden plaatsen. Daarbij treden er veranderingen op in toonhoogte, tempo en luidheid (Rietveld \& van Heuven, 2009). Zo valt bijvoorbeeld het einde van een volledig 


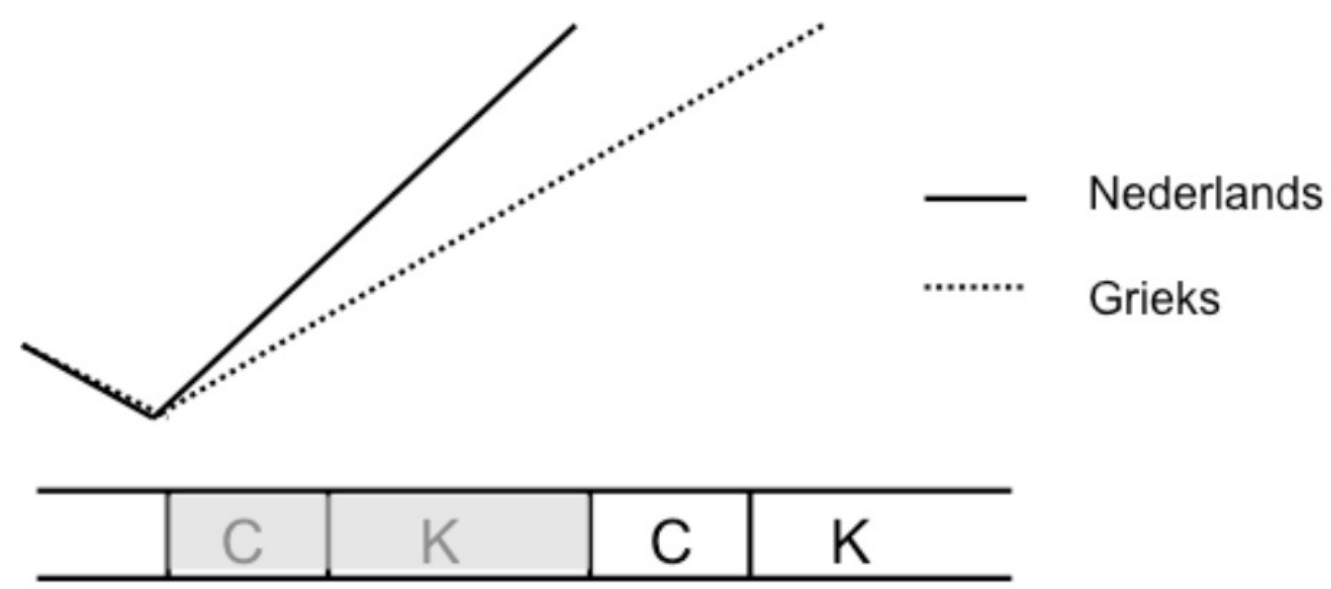

Figuur 4: Schematische weergave van de plaats waar in de lettergreep de toonhoogte in het Grieks en het Nederlands haar piek bereikt. C verwijst naar consonant, K naar Klinker. De beklemtoonde lettergreep is grijs gearceerd.

intonatiepatroon normaliter samen met het einde van een grammaticale structuur (zoals een zin, of een zinsdeel). Een belangrijke rol van intonatie is dus die van 'gesproken interpunctie' (De Rooij, 1979), die net als de interpunctie in geschreven taal, de luisteraar in staat stelt vast te stellen welke woorden of zinsdelen bij elkaar horen en de luisteraar helpen de zin te begrijpen (Nolan, 2006). In de voorbeelden in (7) and (8) zien we hoe we aan de hand van de intonatie kunnen bepalen of we het hebben over 'boter, koekjes en limonade' (zoals in 7), oftewel 'boterkoekjes en limonade' (zoals in 8). In beide gevallen zien we een vallend toonhoogteaccent gevolgd door een hoge grenstoon $\left(\mathrm{H}^{*} \mathrm{~L} \mathrm{H} \%\right)$. Belangrijk is hier dat die hoge grenstoon net voor het einde van een intonatiefrase komt. In voorbeeld (7) wordt de grenstoon aan het einde van het woord boter geplaatst, terwijl de grenstoon in voorbeeld (8) pas aan het einde van koekjes komt.

(7)

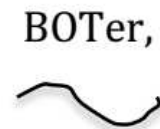

$\mathrm{H}^{*} \mathrm{~L} \quad \mathrm{H} \%$
KOEKjes en limoNADE

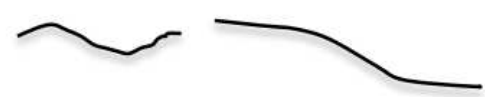

(8)

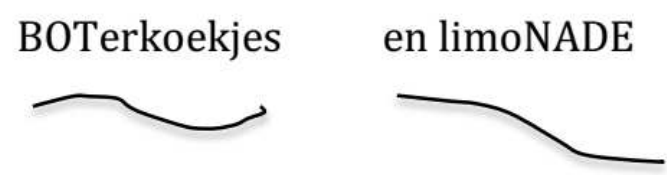

$\mathrm{H}^{*} \mathrm{~L} \quad \mathrm{H} \%$ 
Andere voorbeelden zijn zinnen die zonder interpunctie identiek zouden zijn, zoals in onderstaande voorbeelden.

(9) Marij vraagt: "Anna, ga je naar dat feest?"

(10) "Marij”, vraagt Anna, "ga je naar dat feest?"

De zinnen hebben dezelfde reeks woorden die in dezelfde volgorde voorkomen. Toch hebben ze twee verschillende betekenissen die schriftelijk door de interpunctie wordt weergegeven. In (9) vraagt Marij aan Anna of ze naar het feest gaat, terwijl in (10) de rollen zijn omgekeerd. Wat in geschreven taal wordt weergegeven door punten, komma's, en accenttekens, wordt in gesproken taal weergegeven door intonatie, maar met andere prosodische middelen zoals spreekpauzes, of versnellingen en vertragingen van het spreektempo. Het voorbeeld in (9) wordt typisch uitgesproken met een toonhoogtestijging (dwz. een hoge grenstoon, $\mathrm{H} \%$ ) en een spreekpauze of vertraging na het woord vraagt, terwijl in (10) deze verandering in toonhoogte en tempo plaatsvindt na Marij. Het is ook mogelijk om met intonatie de frasegrenzen aan te geven in zinnen waar de zinsconstructie dubbelzinnig of ambigue is. Wordt bijvoorbeeld de zin 'Peter volgt de man met zijn motor' uitgesproken met een grensmarkering na volgt, dan leidt dit tot de interpretatie dat het de man met de motor is die door Peter gevolgd wordt. Een grensmarkering na het woord man zou eerder leiden tot de interpretatie dat Peter tijdens het rijden van een motor de man aan het volgen is.

Intonatie kan ook aangeven welk woord of zinsdeel belangrijke informatie weergeeft. We hadden al gezien dat luisteraars door de aan- of afwezigheid van een toonhoogteaccent kunnen horen of een lettergreep beklemtoond is of niet. Elk woord heeft potentieel een beklemtoonbare lettergreep, dwz. een lettergreep waar de klemtoon op gelegd kan worden. Maar niet elke beklemtoonde lettergreep is even belangrijk. Zo kunnen we door middel van een abrupte verandering van toonhoogte bepaalde lettergrepen, woorden of zinsdelen extra nadruk geven. Met deze accent-verlenende toonhoogteverandering plaatst de spreker de kern van de boodschap in focus, zodat de luisteraar kan onderscheiden welk deel van de uiting belangrijk is. De focus in de zin 'Maria rijdt morgen naar Italië' kan veranderen afhankelijk van de vraag die met de zin beantwoordt wordt. In antwoord op de vraag 'Wie rijdt morgen naar Italië?' wordt 'Maria' geaccentueerd. Als de vraag 'Hoe gaat Maria morgen naar Italië?' is, zal het woord 'rijdt' in focus zijn. Het woord 'morgen' zal benadrukt worden als gevraagd wordt wanneer Maria naar Italië rijdt, terwijl 'Italië' het accent krijgt als gevraagd wordt waarheen Maria rijdt. In veel talen, maar lang niet alle, is er ook sprake van deaccentuatie. Een woord dat normaal een accent zou krijgen wordt dan niet geaccentueerd. In bovenstaand voorbeeld zou normaal (in een neutrale uitspraak) het zinsaccent op het woord 'Italië' vallen. Maar als een ander woord in focus is zien we dat het geen accent meer krijgt. Deaccentuatie is dus het tegenovergestelde van accentuatie.

Intonatie kan ook een rol spelen in conversaties. Hier spelen voornamelijk de grenstonen een belangrijke rol. Zo geeft een dalende grenstoon (L\%) aan dat de spreker klaar is en dat hij of zij de beurt aan een ander geeft. Een vlakke grenstoon (waar de toonhoogte 
gelijk blijft, aangeduid met $0 \%$ ) geeft aan dat de spreker nog niet is uitgepraat, terwijl een hoge grenstoon $(\mathrm{H} \%)$ op een vraag duidt. In geschreven taal zouden deze functies aangeduid worden met een punt voor de lage grenstoon, een komma voor de vlakke grenstoon en een vraagteken voor de hoge grenstoon (Caspers, 2007).

Daarnaast kan intonatie ook attitude en emotie weergeven. Zo kan intonatie informatie geven over de houding van een bepaalde spreker ten opzichte van een gesprekspartner. Men kan bijvoorbeeld horen of de spreker goedgezind is naar de gesprekspartner of geen zin heeft in het gesprek. Zo zal een positieve attitude vaak leiden tot veel toonhoogtevariatie of een groter toonhoogtebereik, terwijl een routinematig gesprek (of verveeldheid) vaak gekenmerkt wordt door een vlakkere intonatie. Daarnaast kan intonatie de luisteraar er ook op attenderen hoe de spreker zich voelt. Zo gaat verdriet vaak gepaard met een vlakke intonatie, terwijl blijdschap vaak samengaat met een hoge spreektoonhoogte (Van Bezooijen, 1988). Het signaleren van attitude en emotie is voornamelijk een kwestie van gradatie: een grotere of kleinere toonhoogtebeweging, een snellere of langzamere stijging, enzovoorts. Dit betekent dat attitude en emotie grotendeels met realisatieverschillen uitgedrukt worden en niet zo zeer door de keuze van intonatiepatronen (Rietveld \& van Heuven, 2009). Alhoewel de rol van intonatie in de uitdrukking van attitude en emotie onmiskenbaar is, moet benadrukt worden dat dit een heel complex fenomeen is. Het is namelijk niet gemakkelijk om iemands attitude te bepalen en nóg moeilijker om het te onderscheiden van iemands gevoelens of psychologische toestand. Om deze reden bespreken we de rol van attitude en emotie in dit artikel niet verder.

Als laatste heeft intonatie ook een zogeheten 'indexicale' functie, waar intonatie fungeert om iemands persoonlijke of sociale identiteit weer te geven. Zo kan men intonatiepatronen gebruiken die specifiek door een bepaalde groep worden aangenomen om aan te geven dat men bij die groep behoort. Een bekend voorbeeld is het gebruik van een vragende intonatie (met een hoge grenstoon aan het eind) in stellende zinnen, alsof er een vraagteken aan het einde van de zin staat. Dit fenomeen - dat 'uptalk' genoemd wordt - hoor je vaak in het Engels gesproken door jongeren, vooral meisjes, in Noord-Amerika, Australië en NieuwZeeland (Britain, 1992; Cruttenden, 1994). Mensen, en misschien vooral jongeren, willen zich graag onderscheiden en intonatie is een middel dat ze kunnen gebruiken om te laten zien dat ze anders zijn. Zo zijn er in het Utrechtse Lombok autochtone Nederlandse jongeren die de uitspraak van hun allochtone (Marokkaanse en Turkse) leeftijdsgenoten imiteren. Dit doen ze o.a. door aan het begin van een zin de toonhoogte ineens steil (wel een octaaf) omhoog te laten gaan, iets dat we normaal in het Nederlands niet doen. Zo onderscheiden deze Nederlandse jongeren zich van andere groepen, naar eigen zeggen om stoer te klinken (Nortier, 2001).

Net zoals talen en dialecten verschillen in de set intonatiepatronen en hoe ze uitgesproken worden, verschillen ze ook in de functies van intonatie. Zo kunnen talen verschillen in hoe ze vragen markeren. In het Nederlands gaan vragen meestal gepaard met een stijgende toonhoogte (een hoge grenstoon, H\%) op de laatste lettergreep. In andere talen, zoals het 
Grieks of het Hongaars, zien we juist meestal een daling (dus een lage grenstoon, L\%) aan het einde van een vraag (Ladd, 2008). Sommige talen, zoals bijvoorbeeld het Chinees, maken daarentegen in vraagzinnen nauwelijks of geen gebruik van grenstonen. In plaats daarvan spreken ze de hele zin op een wat hoger toonhoogteniveau uit (Shen, 1990). In het Engels gesproken in Belfast, zijn het net de stellende zinnen die eindigen op een hoge grenstoon. In de meeste andere varianten van het Brits Engels zijn het de vragen die eindigen op een hoge grenstoon, nét als in het Nederlands. Talen kunnen ook van elkaar verschillen in hoe ze focus aangeven. In veel talen wordt focus uitgedrukt door een abrupte verandering in toonhoogte. In andere talen gebruiken ze een specifiek toonhoogteaccent om focus aan te geven. Zo krijgt in het Europees Portugees een neutrale zin een $\mathrm{HL}^{*}$ toonhoogteaccent, terwijl focus uitgedrukt wordt door een $\mathrm{H}^{*} \mathrm{~L}$ toonhoogteaccent. Andere talen (bijv. Griekse of Romaanse talen) geven eerder belangrijke informatie aan door middel van woordvolgorde dan door middel van accentuatie. Daarbij verschillen talen ook in de reikwijdte van een accent. Zo zullen Nederlandse sprekers het accent op het bijvoeglijk naamwoord leggen als ze de kleur wil benadrukken in 'een blauwe driehoek', maar op het zelfstanding naamwoord als de vorm benadrukt wordt. Een Italiaanse of Franse spreker zal daarentegen zowel het bijvoeglijk als het zelfstanding naamwoord benadrukken, waardoor de luisteraar geen informatiestatus van het gesprokene kan afleiden (Swerts e.a., 2002; Rasier \& Hiligsmann, 2007).

\section{Verschillen in gebruiksfrequentie van intonatiepatronen}

Een vierde aspect van intonatie waarin talen en dialecten van elkaar kunnen verschillen is de frequentie waarmee bepaalde toonhoogteaccenten, grenstonen, en intonatiepatronen worden gebruikt. Zelfs als talen of dialecten eenzelfde fonologisch systeem hebben (en dus gelijk zijn in de systemische dimensie van intonatie) kunnen ze toch vaak verschillen in de gebruiksfrequentie van intonatiepatronen. Zo gebruiken sprekers van het Brits Engels vaker toonhoogteaccenten die dalen $\left(\mathrm{H}^{*} \mathrm{~L}\right)$, terwijl Nederlandse sprekers net vaker stijgende toonhoogteaccenten $\left(\mathrm{L}^{*} \mathrm{H}\right)$ gebruiken (Willems, 1982). Een vergelijking van vrouwelijke sprekers uit Noord-Duitsland en Zuid-Engeland vond ook meer dalingen in het Zuid-Engels dan in het Noord-Duits (Mennen e.a., 2012). Zulke verschillen in gebruiksfrequentie zien we ook in dialecten. Zo zijn stijgende toonhoogteaccenten veel frequenter in het Belfast Engels dan in het Engels gesproken in Londen of Cambridge, met een frequentie van meer dan $94 \%$ in het Belfast Engels, vergeleken met $54 \%$ voor Londen en $47 \%$ voor Cambridge (Grabe, 2004).

\section{Afwijkende intonatie}

Er is nog maar weinig onderzoek gedaan naar afwijkende intonatie. Tot nu toe heeft dit onderzoek zich voornamelijk gericht op volwassen tweede taalverwervers. Daarnaast zijn er een klein aantal studies waarin onderzocht wordt in hoeverre intonatie geproduceerd door zich normaal ontwikkelende kinderen afwijkt van volwassen intonatie. Ook wordt onderzoek gedaan naar intonatieafwijkingen in een beperkt aantal klinische populaties. In deze 
sectie wordt eerst een kort overzicht gegeven van bestaande testen en andere gebruikte methodes om afwijkende intonatie vast te leggen. Daarna worden intonatieafwijkingen in verschillende onderzoekspopulaties besproken, en zover mogelijk geclassificeerd volgens de eerder beschreven dimensies van intonatie.

\section{Beoordeling van afwijkende intonatie}

Het is belangrijk om te bepalen of en op welke manier intonatie afwijkt van de verwachting. Belangrijk hierbij is dat er een onderscheid gemaakt wordt tussen de verschillende dimensies waarin intonatie afwijkt. Er zijn namelijk 'verschillende soorten verschillen' in intonatie (Ladd, 2008), zoals eerder in dit artikel werd besproken. Het bepalen van de dimensie waarin de intonatie afwijkt van de verwachting kan aangeven waar precies het probleem ligt zodat er in therapie, of in het geval van tweede taalverwervers tijdens taalonderwijs, hierop ingespeeld kan worden..

\section{Gepubliceerde testen ter beoordeling van afwijkende intonatie}

Naar mijn weten is er geen enkele test die uitsluitend gewijd is aan de beoordeling van intonatie. Wél zijn er een aantal testen voor prosodie ontwikkeld, waarbij sommige testonderdelen gebruikt kunnen worden voor het diagnosticeren van afwijkende intonatieaspecten. De meest uitgebreide beoordelingsprocedures voor prosodie zijn de twee versies van Profiling Elements of Prosodic Systems (PEPS en PEPS-C), waarvan de eerste ontwikkeld en genormeerd is voor volwassenen (Peppé, 1998), en de tweede voor kinderen (Wells e.a., 2004). Beide versies onderzoeken zowel receptieve als expressieve prosodische vaardigheden in parallelle taken. De procedure bestaat uit vier soorten taken: 'input' vorm, 'input' functie, 'output' vorm en 'output' functie (Peppé \& McCann, 2003). De 'input' vorm betreft het vermogen om het verschil tussen verschillende prosodische vormen te horen. Een voorbeeld is het verschil tussen 'boter, koekjes en limonade' (met een hoge grenstoon aan het einde van het woord boter) en 'boterkoekjes en limonade' (met een grenstoon aan het einde van koekjes. De testpersoon wordt gevraagd om aan te geven of de twee uitingen die ze horen wel of niet hetzelfde zijn. De 'input' functie betreft het vermogen om de betekenis van deze verschillen te herkennen. De testpersoon moet naar het juiste plaatje wijzen. De 'output' vorm betreft het vermogen om prosodie op de juiste manier te realiseren. Bijvoorbeeld, er wordt getest of de testpersoon de manier waarop 'RODE en groene sokken' gezegd wordt precies kan imiteren (dwz. met nadruk op RODE in dit voorbeeld). De 'output' functie betreft het vermogen om prosodie zinvol te gebruiken voor een aantal standaard communicatiedoeleinden. Dit test bijvoorbeeld of de testpersoon de grenstoon in 'boter, koekjes en limonade' of 'boterkoekjes en limonade' op de juiste plaats kan zetten.

Een van de voordelen voor de klinische praktijk is dat de PEPS en PEP-C genormeerd zijn. Dat maakt het mogelijk om te bepalen óf en in welke mate prosodie afwijkt van de norm. Een ander voordeel is dat het redelijk eenvoudig is de test af te nemen, alhoewel het wel aan te raden is om zich eerst vertrouwd te maken met de procedure. Daarnaast is de 
test beschikbaar in een aantal talen, waaronder het Nederlands. Een nadeel van de test is dat de intonatieproblemen niet geclassificeerd worden in de vier dimensies waarin intonatie kan afwijken (systemische afwijkingen, realisatieafwijkingen, semantische afwijkingen, en afwijkingen in de gebruiksfrequentie). De PEPS en PEPS-C beperkt zich tot de semantische dimensie (dwz. de functies van intonatie) en de mate waarin de testpersoon die functies begrijpt en produceert. Mochten er afwijkingen in de productie geconstateerd worden, kan deze test niet bepalen of dit veroorzaakt wordt door de afwezigheid van bepaalde toonhoogteaccenten of grenstonen (systemische dimensie), of dat het ligt aan de specifiekerealisatie (realisatie-dimensie) of de gebruiksfrequentie (gebruiksfrequentie-dimensie) van deze elementen.

Naast de PEPS en PEPS-C zijn er ook protocollen te vinden voor het beoordelen van prosodie in gepubliceerde testen ontwikkeld voor neurogene spraakstoornissen, zoals bijvoorbeeld het Nederlandstalig dysartrieonderzoek volwassenen (NDO-V; Knuijt e.a., 2014) of de Engelstalige Frenchay Dysarthria Assessment (Enderby, 1983). In deze testen wordt intonatie echter zéér summier onderzocht en beperkt zich tot de auditieve (en daarmee subjectieve) beoordeling van een klein aantal realisatie-aspecten van intonatie, zoals de gemiddelde toonhoogte en het toonhoogtebereik. Deze testen geven daarom geen volledig beeld van de mogelijke dimensies waarin intonatie kan afwijken van de norm.

\section{Andere methodes voor de beoordeling van afwijkende intonatie}

Om intonatie goed te beoordelen is het belangrijk om bij het vergaren van data een balans te vinden tussen natuurlijkheid en controle. Aan de ene kant is het belangrijk om spraak op te nemen die natuurlijk en representatief is voor de spreker. Maar we zagen al eerder dat stemloze medeklinkers zorgen voor onderbrekingen in het grondtoonpatroon (f0), met als gevolg dat intonatiepatronen soms moeilijker te zien en te beoordelen zijn. Ook zagen we dat intonatie en andere prosodische kenmerken (zoals bijv. klemtoon, woord- of zinslengte) elkaar wederzijds beïnvloeden. Daarom willen onderzoekers vaak precies bepalen welke uitingen ze opnemen, vooral als ze verschillende sprekers met elkaar willen vergelijken. Zo worden vaak spreektaken ontwikkeld met testwoorden of -frases die uitsluitend uit sonoranten (klanken die geproduceerd worden met een continue, niet-turbulente luchtstroom: bijv. klinkers, nasalen, approximanten) bestaan. Om die reden wordt er vaak gebruik gemaakt van leestaken, waarbij speciaal ontwikkelde passages of zinnen (met veel sonoranten) worden voorgelezen. Door leespassages te creëren met een variatie aan indirecte en directe spraak, korte en lange zinnen, stellende en vragende zinnen, enz., kan men de passage levendig houden en toch een hoge mate van controle over het spraakmateriaal behouden. Een andere manier om representatieve data te verkrijgen is door een combinatie van leestaken, semi-spontane taken, en spontane spraak te vergaren (zie bijvoorbeeld Grabe e.a., 2001).

Bij kinderen wordt vaak gebruik gemaakt van semi-spontane spreektaken, waarbij door middel van plaatjes spraak wordt ontlokt. Zo gebruikten bijvoorbeeld Romøren \& Chen $(2014,2016)$ plaatjes om focus bij kinderen te ontlokken. De onderzoekers laten het kind 
een plaatje zien van een hond die iets onder een doos verstopt heeft en zeggen 'Kijk, een hond, en de hond verbergt iets', gevolgd door de vraag 'Wat verbergt de hond?'. Samen met het kind wordt er dan gezocht naar het missende plaatje, waarna het kind het antwoord op de vraag geeft (bijv. 'De hond verbergt de trein'). Een andere procedure die de laatste tijd veel gebruikt wordt om spraak te ontlokken is de zogenaamde Diapix-taak (van Engen e.a., 2010; Baker \& Hazan, 2011). Deze taak is ontworpen om een dialoog te creëren tussen twee gesprekspartners, die moeten samenwerken om verschillen tussen twee zeer vergelijkbare foto's te vinden. De gesprekspartners zien elkaars foto's niet. De taak is ontworpen om een breed scala van uitingen (vragen, antwoorden, beschrijving, uitroepen, etc.) te ontlokken en ervoor te zorgen dat beide sprekers een gelijke rol in de conversatie hebben.

\section{Intonatieafwijkingen in zich normaal ontwikkelende kinderen}

Er wordt vaak gezegd dat prosodie, en met name intonatie, een van de eerste dingen is die een kind leert. Misschien is het inderdaad waar dat kinderen al op jonge leeftijd toonhoogtevariatie gebruiken en de elementen van intonatie dus tot op zekere hoogte tot hun beschikking hebben. In hoeverre dit echter op een volwassen manier gebeurt valt te betwisten. Het feit dat kinderen al vroeg dalingen en stijgingen produceren betekent dat ze de fonologie (de tonale inventaris of elementen daarvan) al snel tot hun beschikking hebben. Zo is er bij Nederlandse kinderen vastgesteld (Chen \& Fikkert, 2007) dat ze de tonale inventaris van toonhoogteaccenten en grenstonen (dus de systemische dimensie van intonatie) grotendeels onder de knie hebben op het moment dat ze een woordenschat van ongeveer 230 woorden hebben. Er ontbreken dan echter nog een aantal van de meer gecompliceerde toonhoogteaccenten (bijv. de combinaties van drie tonen, zoals de L*HL). Ook Engelse kinderen hebben de tonale inventaris van hun taal grotendeels tot hun beschikking op een leeftijd van 1 1/2 à 2 jaar (Snow, 2006). Deze leeftijd is natuurlijk slechts een indicatie, want kinderen verschillen nogal in snelheid van ontwikkeling. Wat bovendien is aangetoond is dat de ontwikkeling van intonatie samenhangt met een groei van de woordenschat (Chen \& Fikkert, 2007), dus hoe sneller de woordenschat zich ontwikkelt hoe sneller een kind de tonale inventaris gebruikt.

Maar er zijn meer aspecten van intonatie die kinderen moeten leren. Ze moeten bijvoorbeeld de verschillende functies van intonatie leren, zoals hoe ze woorden en woordeenheden in zinnen samen moeten voegen of scheiden, of hoe bijvoorbeeld focus gemar-

keerd wordt. Daarnaast moeten ze leren welk intonatiepatroon in welke situatie gebruikt wordt, en of bepaalde patronen vaker voorkomen in hun taal of dialect dan andere. Bovendien moeten ze leren hoe een intonatiecontour precies uitgesproken wordt in hun taal, bijvoorbeeld waar in de beklemtoonde lettergreep een stijging begint, hoe snel de stijging is, of wat de relatieve hoogte van toonhoogteaccenten is. Uit onderzoek blijkt dat kinderen deze semantische- , realisatie- , en gebruiksfrequentie-dimensies van intonatie later onder de knie hebben dan de systemische. Zo vonden Chen \& Fikkert (2007) dat de Nederlandse $1 ; 4$ tot 2;1 jarige kinderen de toonhoogteaccenten in twee-woord zinnetjes meestal op beide woorden plaatsen of willekeurig op één van de woorden, terwijl in de context verwacht werd 
dat nadruk op een bepaald woord werd gelegd en het andere woord gedeaccentueerd zou worden. De kinderen blijken op die leeftijd nog te experimenteren met de plaatsing van toonhoogteaccenten en hebben blijkbaar nog niet door hoe focus van invloed is op de intonatie. Dát krijgen ze pas door als ze vier of vijf jaar oud zijn. Vanaf die leeftijd plaatsen kinderen, net als volwassenen, het toonhoogteaccent grotendeels op het focale zinsdeel en deaccentueren ze de daarop volgende informatie (Chen, 2011). Toch verschillen ze op die leeftijd nog van volwassenen. Zo gebruiken Nederlandstalige vier- tot vijfjarigen bijvoorbeeld verschillende toonhoogteaccenten om focus aan te geven, terwijl Nederlandstalige volwassenen de voorkeur geven aan een dalend $\left(\mathrm{H}^{*} \mathrm{~L}\right)$ toonhoogteaccent (Chen, 2011). Het vermogen om gefocuste informatie prosodisch te markeren blijft zich ontwikkelen totdat op ongeveer elfjarige leeftijd volwassen normen worden bereikt (Romøren \& Chen (2016). Tijdens die ontwikkeling spelen een aantal factoren een rol. Zo is het moeilijker voor kinderen om focus te markeren in complexe zinnen dan in eenvoudige, korte zinnen (Romøren \& Chen, 2014). Ook bereiken kinderen eerder volwassen vaardigheden in zinsfinale positie dan in zinsmediale positie (Chen, 2014; Romøren \& Chen, 2014). Daarnaast heeft onderzoek aangetoond dat er cross-linguïstische verschillen zijn in de snelheid waarmee kinderen volwassen vaardigheden verwerven. Zweedssprekende kinderen blijken bijvoorbeeld iets voor te lopen op hun Nederlandssprekende leeftijdsgenoten bij de verwerving van het prosodisch markeren van focus in hun taal (Romøren \& Chen (2016). Verder onderzoek moet nog aantonen in hoeverre dit veroorzaakt wordt door prosodische verschillen tussen talen en in hoeverre deze van invloed zijn op de snelheid van ontwikkeling.

Over de verwerving van realisatie-aspecten van intonatie weten we nog weinig. Recent onderzoek heeft echter aangetoond dat kinderen éérst de fonologische aspecten (de tonale inventaris oftewel de systemische dimensie van intonatie) verwerven voordat ze leren hoe intonatiepatronen precies uitgesproken worden (het fonetische aspect oftewel de realisatiedimensie van intonatie). Maar de fonetische aspecten lopen niet erg ver achter. AstrucAguilera e.a. (2009; 2013) vonden dat Spaanse, Catalaanse, en Engelse kinderen al op tweejarige leeftijd bepaalde realisatie-aspecten van intonatie (zoals de timing en hoogte van toonhoogteaccenten) produceren. Dit wil echter niet zeggen dat kinderen dan al de volwassen norm bereikt hebben. Astruc-Aguilera e.a. (2009; 2013) vonden dat de precisie toeneemt naarmate de leeftijd van de kinderen toeneemt: de zesjarige kinderen in hun studie waren dichter bij de volwassen norm dan de tweejarige kinderen. Toch hebben zelfs de zesjarige kinderen de volwassen norm nog niet helemaal bereikt. Toekomstig onderzoek moet aangeven op welke leeftijd kinderen de volwassen norm bereiken.

Wat betreft de gebruiksfrequentie van intonatiepatronen verschillen kinderen ook van volwassenen. Zo rapporteren Chen \& Fikkert (2007) dat de Nederlandse 1;4 tot 2;1 jarige kinderen in hun studie duidelijk meer dalingen dan stijgingen produceren, terwijl we dit niet zouden verwachten in volwassen sprekers van het Nederlands (zie Willems, 1982). Dit betekent dat kinderen op deze leeftijd de specifieke gebruiksfrequentie van toonhoogteaccenten in hun taal nog niet verworven hebben. 


\section{Intonatieafwijkingen in volwassen tweede taalverwervers}

Een belangrijk doel in onderzoek naar de intonatie van volwassen tweede taalverwervers is om de relatieve moeilijkheid te voorspellen die taalverwervers met bepaalde aspecten van intonatie zullen ondervinden. Net als sommige klanken in een tweede taal moeilijker uit te spreken zijn dan andere, zijn ook niet alle aspecten van intonatie even moeilijk. Bovendien zullen moedertaalsprekers van het Chinees andere problemen ondervinden bij het produceren van Engelse intonatie dan moedertaalsprekers van het Nederlands. Om te voorspellen welke aspecten voor welke taalleerders problemen zullen opleveren is het belangrijk om de intonatie van de moedertaal te vergelijken met de intonatie van de taal die geleerd wordt (de tweede taal, ook doeltaal genoemd) en te bestuderen welke van deze verschillen leiden tot afwijkingen van de norm. Het is nuttig gebleken voor het bestuderen van tweede taalverwerving om intonatieafwijkingen te classificeren in de vier eerder genoemde dimensies waarin intonatie kan afwijken: systemische afwijkingen, realisatieafwijkingen, semantische afwijkingen, en afwijkingen in de gebruiksfrequentie. Zo kan bepaald worden in welk aspect van intonatie afwijkingen ten opzichte van moedertaalsprekers zich voordoen en of ze bijvoorbeeld vaker voorkomen in sommige dan in andere aspecten. Het maakt het ook mogelijk om systematisch de rol van allerlei factoren die van invloed kunnen zijn op het leerproces te bestuderen, zoals o.a. de invloed van de moedertaal, de leeftijd waarop de tweede taal geleerd wordt, of het aantal jaren ervaring. Zo weten we nu dat afwijkingen van de doeltaal voorkomen in elk van de vier intonatie-dimensies.

Een voorbeeld van een systemische afwijking van de doeltaal is wanneer tweede taalverwervers toonhoogteaccenten die niet in de moedertaal voorkomen weglaten. Zo werden er geen complexe toonhoogteaccenten (zoals $\mathrm{H}^{*} \mathrm{LH}$ of $\mathrm{L}^{*} \mathrm{HL}$ ) gevonden in het Engels gesproken door moedertaalsprekers van het Italiaans en Punjaabs, ondanks het feit dat deze in de doeltaal (het Engels gesproken in Londen) wél regelmatig voorkomen (Mennen e.a., 2010). Jilka (2000) geeft een voorbeeld van verschillen tussen moedertaalsprekers van het Amerikaans en het Duits. In het Duits wordt een continuering (om aan te geven dat er nog meer informatie komt) uitgedrukt met een stijgend toonhoogteaccent gevolgd door een vlakke grenstoon $\left(\mathrm{L}^{*} \mathrm{H} 0 \%\right)$, terwijl dit in het Amerikaans Engels uitgedrukt wordt door een hoog toonhoogteaccent, waarna de toonhoogte op het laatste woord in de intonatiefrase eerst daalt en dan stijgt ( $\left.\mathrm{H}^{*} \mathrm{LH} \%\right)$. Jilka (2000) vond dat Amerikaanse moedertaalsprekers die Duits als tweede taal hadden dit Amerikaanse continueringspatroon ook in het Duits gebruikten, terwijl dit patroon niet tot de Duitse tonale inventaris behoort.

De meeste afwijkingen worden gevonden in de realisatie van intonatie (Mennen, 2015). Veel studies rapporteren verschillen in, onder andere, de timing en hoogte van toonhoogte accenten. Zo beginnen stijgingen in de productie van het Engels als tweede taal door moedertaalsprekers van het Duits pas in de [m] of de [i] van 'mineral' in een zin als 'He took a mineral enriched supplement every morning', terwijl Engelse moedertaalsprekers al vóór het woord 'mineral' met die stijging beginnen (Atterer \& Ladd, 2004). Afwijkingen van de norm worden ook regelmatig gerapporteerd voor de hoogte van toonhoogteaccenten of grensto- 
nen. Zo worden toonhoogteaccenten in de productie van het Engels als tweede taal door moedertaalsprekers van het Nederlanders vaak uitgesproken met een te groot en te steil toonhoogteverloop. Ook eindigen ze hun zinnen vaak op een te hoog niveau met een te hoge grenstoon (Willems, 1982).

Er zijn ook semantische afwijkingen in de intonatie van tweede taalverwervers geconstateerd. Bijvoorbeeld, Wennerstrom (1994) vond dat bij de productie van het Engels als tweede taal door moedertaalsprekers van het Japans, Thai en Spaans nieuwe informatie niet consequent gemarkeerd werd door een hoog toonhoogteaccent $\left(\mathrm{H}^{*}\right)$. Vergelijkbare problemen met het markeren van focus werden o.a. ook gemeld in de productie van het Engels als tweede taal door moedertaalsprekers van het Chinees (Juffs, 1990) en Zulu (Swerts \& Zerbian, 2010). Vaak hebben tweede taalverwervers ook problemen met het deaccentueren van informatie die niet in focus is (Grosser, 1997; Gut, 2009).

Als laatste bestaat er ook bewijs voor afwijkingen in de frequentie waarmee toonhoogteaccenten, grenstonen, en intonatiepatronen worden gebruikt. Zo werd in deproductie van het Engels als tweede taal door moedertaalsprekers van het Nederlands geconstateerd dat het percentage stijgingen beduidend hoger was dan dat van de Engelse moedertaalsprekers (Willems, 1982). Engelse moedertaalsprekers gebruiken eerder dalingen. Dit soort verschillen in de frequentie waarmee toonhoogteaccenten of grenstonen worden gebruikt wordt gerapporteerd voor een groot aantal moedertaal- en doeltaalcombinaties.

\section{Intonatieafwijkingen in klinische populaties}

In deze sectie geven we een aantal voorbeelden van klinische populaties waarvan bekend is dat intonatie vaak afwijkt van de norm. De bedoeling is niet om een volledig overzicht te geven van alle klinische populaties waar intonatie afwijkend is, maar om te illustreren welke dimensies van intonatie problemen kunnen leveren en hoe dit zich kan manifesteren.

\section{Intonatie in neurogene spraakstoornissen}

Het is bekend dat prosodische verstoringen een belangrijke rol spelen in neurogene spraakstoornissen, zoals dysartrie of spraakapraxie. Daarbij is ook de intonatie vaak aangetast. In deze spraakstoornissen verloopt de articulatie over het algemeen moeizaam en is de spraak vaak wat vertraagd, waardoor de behoefte om adem te halen vaak vergroot is. Het nemen van meer frequente adempauzes verstoort de prosodie en kan de indruk geven dat de spraak niet vloeiend is (Peppé, 2009). Over het algemeen heeft onderzoek aangetoond dat de intonatieafwijkingen die in motorische spraakstoornissen optreden voornamelijk afwijkingen in de realisatiedimensie van intonatie betreffen. Mennen e.a. (2008) vergeleken aan de hand van een leestaak de intonatie van twee Britse sprekers met een hypokinetische dysartrie (als gevolg van de ziekte van Parkinson) en twee gezonde sprekers als controlepersonen. De sprekers met de ziekte van Parkinson bleken dezelfde categorische elementen (toonhoogteaccenten en grenstonen) als de gezonde controlepersonen te hebben. Dus er waren geen 
systemische (fonologische) verschillen tussen de twee groepen. De verschillen tussen de twee groepen lagen daarentegen in afwijkingen in de realisatie- en gebruiksfrequentiedimensies van intonatie. De sprekers met de ziekte van Parkinson hadden bijvoorbeeld een kleiner toonhoogtebereik (realisatie), kortere intonatiefrases (realisatie), en een kleiner aantal toonhoogteaccenten (gebruiksfrequentie). Daarnaast plaatsten ze de toonhoogteaccenten vaak op plaatsen die niet samenvielen met een belangrijke breuk in de zinsstructuur, waardoor de fraseringsfunctie (semantische dimensie) van intonatie verstoord raakte. Verdere functies van intonatie werden niet in deze studie getest. Er werd geconcludeerd dat in sprekers met een hypokinetische dysartrie als gevolg van de ziekte van Parkinson de abstracte representatie van intonatie niet is aangetast, en dat de problemen eerder motorisch van aard zijn en liggen in de uitvoering en implementatie van intonatie. Een gelijksoortige conclusie werd getrokken voor sprekers met ataxische dysartrie, een spraakstoornis veroorzaakt door een verstoring in de functie van het cerebellum (Lowit e.a., 2014). Ook daar bleken de intonatieproblemen voornamelijk te liggen in de realisatie-, gebruiksfrequentieen semantische dimensies van intonatie. Net als in de sprekers met de ziekte van Parkinson, werd gevonden dat de sprekers met ataxische dysartrie dezelfde toonhoogteaccenten, grenstonen en intonatiepatronen gebruikten als de gezonde controlesprekers. Maar ze verschilden van de controlegroep in drie aspecten: ze produceerden kortere intonatiefrases, hadden meer toonhoogteaccenten per aantal lettergrepen en deaccentueerden minder.

Een verdere neurogene spraakstoornis waarbij intonatie soms is aangetast is ontwikkelingsdysartrie. Kuschmann e.a. (2016) onderzochten intonatiepatronen in Engelstalige kinderen met ontwikkelingsdysarthrie ten gevolge van hersenverlamming en concludeerden dat ze geen volledige inventaris van toonhoogteaccenten tot hun beschikking hadden. De kinderen gebruikten niet de $\mathrm{L}^{*} \mathrm{H}$ stijgingen die kenmerkend zijn in de stellende zinnen van het Engels gesproken in Tyneside en Newcastle (Grabe, 2004), de regio waar de kinderen vandaan kwamen. Verder ontbraken ook de L*HL en $\mathrm{H}^{*} \mathrm{LH}$, maar eerder onderzoek wees uit dat deze complexe toonhoogteaccenten in deze regio heel weinig voorkomen (Grabe, 2004). Aangezien Kuschmann e.a. (2016) geen gezonde controlesprekers gebruikten is het onduidelijk óf en in hoeverre, naast deze afwijking in de systemische dimensie, andere dimensies van intonatie in kinderen met ontwikkelingsdysarthrie ook afwijkingen vertoonden.

\section{Intonatie in buitenlandsaccent-syndroom}

De meest 'zuivere' prosodische aandoening is waarschijnlijk het buitenlandsaccent-syndroom (Peppé, 2009, p. 9). Dit is een vrij zeldzame spraakstoornis die ertoe leidt dat de uitspraak van de betroffene zodanig verandert dat het klinkt alsof hij/zij een buitenlands accent (of een accent uit een andere regio) heeft. De aandoening is meestal het gevolg van een hersenbloeding of ander hersenletsel. Zo kan het zijn dat een spreker uit Groningen ineens het zangerige Limburgse accent heeft, of een spreker uit Engeland ineens Italiaans klinkt. Verhoeven \& Mariën (2008) beschrijven een geval van een Nederlandse mevrouw die door veranderingen in haar uitspraak klonk alsof ze een Frans accent had. De geconstateerde veranderingen lagen vooral in haar uitspraak van klinkers en medeklinkers, maar er wer- 
den ook een aantal veranderingen in prosodie geconstateerd, zoals een trager spreektempo, veranderingen in ritme, en wat problemen met de intonatie. De intonatieproblemen waren voornamelijk beperkt tot afwijkingen in de realisatie- en gebruiksfrequentie. Ze had geen problemen met het produceren van intonatiecontouren, die in overeenstemming waren met de algemene principes van Nederlandse intonatie en dus welgevormd waren. Met andere woorden, ze had geen problemen met de systemische (fonologische) dimensie van intonatie. Wel was haar tonale inventaris wat kleiner en gebruikte ze alleen de vier meest elementaire intonatiepatronen. De afwijkingen in intonatie betroffen echter voornamelijk de realisatiedimensie van intonatie. Zo was haar toonhoogtebereik met de helft verkleind en was haar gemiddelde stemtoonhoogte aanzienlijk gedaald. Daarnaast maakte ze uitermate veel gebruik van hoge grenstonen. Dit werd geïnterpreteerd als een strategie om aan te geven dat ze nog niet uitgesproken was. Later onderzoek met een grotere groep Engelstalige patiënten met een buitenlandsaccentsyndroom kwam tot heel gelijkwaardige conclusies (Kuschmann, e.a., 2012). Sprekers met het buitenlandsaccentsyndroom hadden dezelfde structurele inventaris tot hun beschikking als controlesprekers (dus de systemische dimensie van intonatie was in orde), maar weken af in de realisatie-, gebruiksfrequentie- en semantische dimensies van intonatie.

\section{Intonatie in Autisme Spectrum Stoornis}

Een van de kenmerken van de spraak van kinderen met Autisme Spectrum Stoornis (ASS) is een afwijkende prosodie (Baltaxe \& Guthrie, 1987). Wat vaak genoemd wordt is dat kinderen met ASS moeite hebben met het begrijpen van ironie of sarcasme, iets wat vaak door middel van intonatie uitgedrukt wordt. Maar ook worden er problemen genoemd met het produceren van intonatie. De spraak van zelfs zeer verbale kinderen met ASS kan ongebruikelijk klinken (Fay \& Schuler, 1980). Een grote variatie van prosodische kenmerken wordt beschreven, zoals een overdreven of net eentonige intonatie, een langzaam tempo, of de aanname van een accent dat niet overeenkomt met het accent van de omgeving (Baron-Cohen \& Staunton 1994). Zo wordt bijvoorbeeld gezegd dat toonhoogteaccenten om focus uit te drukken vaak verkeerd geplaatst worden (Baltaxe \& Guthrie, 1987). Dit zou duiden op een probleem met de semantische aspecten van intonatie. Kinderen met ASS blijken ook moeite te hebben met het imiteren van prosodische functies, zoals focus, emotie, en het aangeven van continuatie. Aangezien er nog maar weinig AM analyses van intonatie in ASS zijn (m.u.v. een kleine studie door Fosnot \& June, 1999) is het onduidelijk in hoeverre - naast de genoemde problemen in de semantische dimensie - intonatie afwijkt in systemischerealisatie- of gebruiksfrequentieaspecten.

\section{Discussie}

Hopelijk heeft dit artikel duidelijk gemaakt dat de autosegmentele-metrische (AM) analyse van intonatie waardevolle informatie kan geven over de aard waarin talen en dialecten in intonatie van elkaar kunnen verschillen. Belangrijk daarbij is de erkenning dat er 'verschil- 
lende soorten verschillen' zijn (Ladd, 2008: 115). Zo werd besproken dat bijvoorbeeld het feit dat het Nederlands een kleiner toonhoogtebereik dan het Brits Engels heeft, een ander soort verschil is dan het feit dat het Nederlands vaker stijgingen gebruikt dan het Engels. Het eerste betreft een verschil in de realisatie-dimensie van intonatie, terwijl het tweede voorbeeld een verschil betreft in de gebruiksfrequentie van intonatie. Hopelijk heeft dit artikel het belang van het onderscheiden van dit soort verschillen duidelijk gemaakt. We zagen dat dit niet alleen belangrijk is in het vergelijken van talen en dialecten, maar vooral ook in het beschrijven van afwijkingen in intonatie. In taalonderwijs is het bijvoorbeeld belangrijk om te weten met welke aspecten van intonatie tweede taalverwervers moeite hebben, en vooral welke van deze van invloed zijn op de communicatie. Zo is het misschien minder belangrijk dat een Duitse spreker van het Engels als tweede taal wat later met een stijging begint dan een moedertaalspreker. Daarentegen kan het verkeerd plaatsen van een grenstoon meer gevolgen voor de communicatie hebben, zodat de luisteraar moeilijk kan bepalen of een spreker uitgesproken is of nog verder wil gaan. Het gebruiken van een verkeerd toonhoogteaccent kan ook leiden tot miscommunicatie. Zo geeft Rietveld e.a. (1999) een anekdote waar tijdens een diner in een restaurant kaas geserveerd werd. De eerste auteur kende de kaas niet en vroeg de serveerster 'What kind of CHEESE is this?' met een \%LL*HH\% intonatiepatroon (laag beginnend, gevolgd door een stijgend toonhoogteaccent op 'cheese' en een hoge grenstoon). Dit werd nóch door de serveerster nóch door de derde auteur geapprecieerd; beiden interpreteerde het als kritiek ('wat is DAT nou voor kaas!').

Deze categorisatie van soorten intonatieafwijkingen is ook belangrijk in het beschrijven van intonatie in klinische populaties. Onderzoek heeft de waarde van de AM analyse laten zien voor het karakteriseren van intonatieafwijkingen. Met name de classificatie van intonatie in de verschillende dimensies (systemisch, realisatie, semantisch, gebruiksfrequentie) maakt het mogelijk om controlesprekers van sprekers met spraakstoornissen te onderscheiden, en zelfs de specifieke intonatieproblemen van verschillende spraakstoornissen te benadrukken (Lowit \& Kuschmann, 2012). Daarmee is hopelijk aangetoond dat deze benadering geschikt is om een gedetailleerd beeld te schetsen van de aard intonatiestoornis waarmee een spreker belast is, en uiteindelijk kan leiden tot een effectievere behandeling. Zoals we zagen kan deze classificatie van intonatie toegepast worden in een groot aantal onderzoeksgroepen, waarvan er hier slechts een klein aantal werden genoemd. We hopen dat dit artikel misschien de aanzet geeft tot een uitbreiding van intonatieonderzoek in verdere doelgroepen.

\section{Dankwoord}

De auteur bedankt een anonieme reviewer voor zeer behulpzaam commentaar op een eerdere versie van dit artikel. 


\section{Referenties}

Anderson-Hsieh, J., Johnson, R., \& Koehler, K. (1992). The relationship between native speaker judgments of nonnative pronunciation and deviance in segmentals, prosody, and syllable structure. Language Learning, 42, 529-555.

Boula de Mareüil, P., \& Vieru-Dimulescu, B. (2006). The contribution of prosody to the perception of foreign accent. Phonetica, 63, 247-267.

Atterer, M., \& Ladd, D. R. (2004). On the phonetics and phonology of 'segmental anchoring' of F0: Evidence from German. Journal of Phonetics, 32, 177-197.

Astruc-Aguilera, L., Payne, E., Post, B., Prieto, P., \& Vanrell, M. M. (2009). Acquisition of tonal targets in Catalan, Spanish and English. Cambridge Occasional Papers in Linguistics, 5, 1-14.

Astruc-Aguilera, L., Payne, E., Post, B., Vanrell, M. M., \& Prieto, P. (2013). Tonal targets in early child English, Spanish, and Catalan. Language and Speech, 56(2), 229-253.

Baker, R, \& Hazan, V. (2011). DiapixUK: a task for the elicitation of spontaneous speech dialogs. Behavior Research Methods, 43, 761-770.

Baltaxe, C. A. M., \& Guthrie, D. (1987). The use of primary sentence stress by normal, aphasic and autistic children. Journal of Autism and Developmental Disorders, 17(2), 255271.

Baron-Cohen, S., \& Staunton, R. (1994). Do children with autism acquire the phonology of their peers? An examination of group identification through the window of bilingualism. First Language, 14, 241-248.

Britain, D. (1992). Linguistic change in intonation: The use of high rising terminals in New Zealand English. Language Variation and Change, 4, 77-104.

Boula de Mareüil, P., \& Vieru-Dimulescu, B. (2006). The contribution of prosody to the perception of foreign accent. Phonetica, 63, 247-267.

Caspers, J. (2007). Punt, komma of vraagteken? De waarneming van zinsfinale intonatie door eerste- en tweedetaalsprekers van het Nederlands. Internationale Neerlandistiek, 45, 2-9.

Chen, A. (2011). Tuning information packaging: intonational realization of topic and focus in child Dutch. Journal of child language, 38(5), 1055-1083.

Chen, A. (2014). Production-comprehension (A)Symmetry: individual differences in the acquisition of prosody focus-marking. In: Proceedings of the 7th International Conference on Speech Prosody.

Chen., A., \& Fikkert, P. (2007). Intonation of early two-word utterances in Dutch. In J. Trouvain, \& B. J. Barry (Eds.), Proceedings of the 16th International Congress of Phonetic Sciences (pp. 315-320). Dudweiler: Pirrot.

Cruttenden, A. (1974). An experiment involving comprehension of intonation in children from 7 to 10. Journal of Child Language, 1, 221-231.

Cruttenden, A. (1994). Rises in English. In J. Windsor Lewis (Ed.), Studies in General and English Phonetics: Essays in Honour of Professor J.D. O'Connor (pp. 155-173). London: Routledge.

Cruttenden, A. (2001). Mancunian intonation and intonational representation. Phonetica, 
58, 53-80.

De Mareüil, P. B., Rilliard, A., Lehka-Lemarachand, I., Mairano, P., \& Lai, J. (2015). Falling yes/no questions in Corsican French and Corsican: Evidence for a prosodic transfer. In E. Delais-Roussarie, M. Avanzi, \& S. Herment (Eds.), Prosody and Language Contact: L2 Acquisition, Attrition, and Languages in Multilingual Situations (pp. 101-122). New York: Springer.

De Rooij, J. J. (1979). Speech punctuation. An accoustic and perceptual study of some aspects of speech prosody in Dutch. Doctoral dissertation, University of Utrecht, Utrecht.

Fay, W., \& Schuler, A. (1980). Emerging Language in Autistic Children. London: Edward Arnold.

Fosnot, S. M., \& Jun, S. (1999). Prosodic characteristics in children with stuttering or autism during reading and imitation. In J. J. Ohala, \& Y. Hasegawa (Eds.), Proceedings of the 14th International Congress of Phonetic Sciences (pp. 1925-1928)."Dordrecht: Foris.

Grabe, E. (1998). Comparative intonational phonology: English and German. Doctoral dissertation, University of Nijmegen, Nijmegen.

Grabe, E. (2004). Intonational variation in urban dialects of English spoken in the British Isles. In P. Gilles, \& J. Peters (Eds.), Regional Variation in Intonation (pp. 9-31). Tuebingen: Niemeyer.

Grabe, E., Post, B. and Nolan, F. (2001). Modelling intonational Variation in English. The IViE system. In Puppel, S. and Demenko, G. (eds). Proceedings of Prosody 2000, 51-57, Adam Mickiewitz University, Poznan, Poland.

Grosser, W. (1997). On the acquisition of tonal and accentual features of English by Austrian learners. In A. James, \& J. Leather (Eds.), Second Language Speech: Structure and Process, (pp. 211-228). Berlin: Mouton de Gruyter.

Gussenhoven, C. (2005). Transcription of Dutch intonation. In S.-A. Jun (Ed.), Prosodic Typology: The Phonology of Intonation and Phrasing (pp. 118-145). Oxford: Oxford University Press.

Gut, U. (2009). Non-native Speech: A Corpus-based Analysis of Phonological and Phonetic Properties of L2 English and German. Frankfurt: Peter Lang.

Haan, J. (2002). Speaking of questions. An exploration of Dutch question intonation. Doctoral dissertation, University of Utrecht, Utrecht.

't Hart, J., \& Cohen, A. (1973). Intonation by rule: a perceptual quest. Journal of Phonetics, $1,309-327$.

Jilka, M. (2000). The Contribution of Intonation to the Perception of Foreign Accent. Doctoral dissertation, University of Stuttgart.

Juffs, A. (1990). Tone, syllable structure and interlanguage phonology: Chinese learners'stress errors. International Review of Applied Linguistics in Language Teaching, 21, 99-115.

Kent, R. D., \& Kim, Y.-J. (2003). Toward an acoustic typology of motor speech disorders. Clinical Linguistics and Phonetics, 17(6), 427-445.

Knuijt, S., Kalf, J. G., Gerven, M. van, Deckers-Kocken, J. M., Kromhout, L., Goossens, H. B., \& Swart, B. J. M. (2014). Nederlandstalig dysartrieonderzoek - volwassenen: NDO-V. Bohn Stafleu van Loghum.

Kuschmann, A., Lowit, A., Miller, N., \& Mennen, I. (2012). Intonation in neurogenic foreign 
accent syndrome. Journal of Communication Disorders, 45, 1-11.

Kuschmann, A., Miller, N., Lowit, A. \& Pennington, L. (2016) Intonation patterns in older children with cerebral palsy before and after speech intervention. International Journal of Speech-Language Pathology. p. 1-28.

Ladd, D. R. (2008). Intonational Phonology (2nd ed.). Cambridge, UK: Cambridge University Press.Ladd, D. R., Mennen, I., \& Schepman, A. (2000). Phonological conditioning of peak alignment in rising pitch accents in Dutch. Journal of the Acoustical Society of America, 107, 2685-2696.

Lowit, A., Kuschmann, A., \& Kavanagh, K. (2014). Phonological markers of sentence stress in ataxic dysarthria and their relationship to perceptual cues. Journal of Communication Disorders, 50, 8-18.

Lowit, A., \& Kuschmann, A. (2012). Characterizing intonation deficit in motor speech disorders: An autosegmental-metrical analysis of spontaneous speech in hypokinetic dysarthria, ataxic dysarthria and foreign accent syndrome. Journal of Speech, Language and Hearing Research, 55(5), 1472-1484.

Magen, H. (1998). The perception of foreign-accented speech. Journal of Phonetics, 26, 38-400.

Mennen, I. (2015). Beyond segments: Towards an L2 intonation learning theory (LILt). In E. Delais-Roussarie, M. Avanzie, \& S. Herment (Eds.), Prosody and Languages in Contact: L2 Acquisition, Attrition and Languages in Multilingual Situations (pp. 171-188). Heidelberg, Springer Verlag.

Mennen, I., Chen, A., \& Karlsson, F. (2010). Characterising the internal structure of learner intonation and its development over time. In K. Dziubalska-Kołaczyk, M. Wrembel, \& M. Kul (Eds.), Proceedings of New Sounds 2010: 6th International Symposium on the Acquisition of Second Language Speech (pp. 319-324). Poznan: Adam Mickiewicz University.

Mennen, I., Schaeffler, F., \& Docherty, G. (2012). Cross-language difference in f0 range: A comparative study of English and German. Journal of the Acoustical Society of America, 131(3), 2249-2260.

Mennen, I., Schaeffler, F., Watt, N., \& Miller, N. (2008). An autosegmental-metrical investigation of intonation in people with Parkinson's Disease. Asia Pacific Journal of Speech, Language, and Hearing, 11(4), 205-219.

Munro, M., \& Derwing, T. (1995). Foreign accent, comprehensibility, and intelligibility in the speech of second language learners. Language Learning, 45, 73-97.

Nolan, F. (2006). Intonation. In B. Aarts, \& A. McMahon (Eds.), Handbook of English Linguistics (pp. 433-457). Oxford: Blackwell.

Nortier, J. M. (2001). Murks en straattaal: vriendschap en taalgebruik onder jongeren. Amsterdam: Prometheus.

Peters, J., Michalsky, J., \& Hanssen, J. (2012). Intonatie op de grens van Nederland en Duitsland: Nedersaksisch en Hoogduits. Internationale Neerlandistiek, 50, 20-39.

Peppé, S.J.E. (1998) Investigating linguistic prosodic ability in adult speakers of English. Unpublished doctoral thesis, University College London.

Peppé, S. J. E. (2009). Why is prosody in speech-language therapy so difficult? International 
Journal of Speech-Language Pathology, 11(4), 258-271.

Peppé, S., \& McCann, J. (2003). Assessing intonation and prosody in children with atypical language development: The PEPS-C test and the revised version. Clinical Linguistics and Phonetics, 17, 345-354.

Pierrehumbert, J. (1980). The phonology and phonetics of English intonation. Unpublished doctoral dissertation. MIT, Cambridge, Massachusetts.

Pierrehumbert, J., \& Beckman, M. E. (1988). Japanese Tone Structure. Cambridge, MA: MIT Press.

Rasier, L. \& Hiligsmann, P. (2007). Prosodic transfer from L1 to L2: Theoretical and methodological issues. Nouveaux Cahiers de Linguistique Française, 28, 41-66.

Rietveld, A. C. M., \& Van Heuven, V. J. (2009). Algemene Fonetiek. Bussum: Coutinho.

Rietveld, T., Gussenhoven, C., Wichmann, A., \& Grabe, E. (1999). Communicative effects of rising and falling pitch accents in British English and Dutch. Proceedings of ESCA Workshop Dialogue and Prosody (pp. 111-116).

Romøren, A. S. H., \& Chen, A. (2014). Accentuation, pitch and pausing as cues to focus in child Dutch. In Proceedings of the 38th Boston University Conference on Language Development (BUCLD). Cascadilla Press.

Romøren, A. S. H., \& Chen, A. (2016). Hunting highs and lows: Acquiring prosodic focus marking in Swedish and Dutch. In Proceedings of the 40th Boston University Conference on Language Development (BUCLD). Cascadilla Press.

Scharff-Rethfeldt, W., Miller, N., \& Mennen, I. (2008). Unterschiede in der mittleren Sprechtonhöhe bei Deutsch/Englisch bilingualen Sprechern. Sprache, Stimme, Gehör, 32, 123128.

Shen, X. (1990). Prosody of Mandarin Chinese. Berkeley: Berkeley University Press.

Snow, D. (2006). Regression and reorganization of intonation between 6 and 23 months. Child Development, 77(2), 281-296.

Swerts, M., Krahmer, E., \& Avesani, C. (2002). Prosodic marking of information status in Dutch and Italian: A comparative analysis. Journal of Phonetics, 30(4), 629- 654.

Swerts, M., \& Zerbian, S. (2010). Intonational differences between L1 and L2 English in South Africa. Phonetica, 67, 127-146.

Van Bezooijen, R. (1988). Spraak, emotie en persoonlijkheid. In M. P. R. Broecke, van den (Ed.), Ter Sprake: Spraak als Betekenisvol Geluid in 36 Thematische Hoofdstukken (pp. 179-189). Dordrecht: Foris Publications.

Van Engen, K. J., Baese-Berk, M., Baker, R. E., Choi, A., Kim, M., \& Bradlow, A. R. (2010). The Wildcat corpus of native- and foreign-accented English: Communicative efficiency across conversational dyads with varying language alignment profiles. Language and Speech, 53, 510-540.

Verhoeven, J. W. M., \& Mariën, P. (2007). Foreign accent syndrome: Segmentele en prosodische kenmerken. Stem-, Spraak- en Taalpathologie, 15(3), 208-228.

Verhoeven, J., \& Mariën, P. (2010). Neurogenic foreign accent syndrome: Articulatory setting, segments and prosody in a Dutch speaker. Journal of Neurolinguistics, 23(6), 599614.

Wells, B., Peppé, S., \& Goulandris, N. (2004). Intonation development from five to thirteen. 
Journal of Child Language, 31(4), 749-778.

Wennerstrom, A. (1994). Intonational meaning in English discourse: A study of non-native speakers. Applied Linguistics, 15, 399-420.

Willems, N. (1982). English Intonation from a Dutch Point of View. Dordrecht: Foris Publications. 